\title{
LEVEL II SCOUR ANALYSIS FOR BRIDGE 25 (JAMATH00010025) on TOWN HIGHWAY 1, crossing BALL MOUNTAIN BROOK, JAMAICA, VERMONT
}

U.S. Geological Survey Open-File Report 97-376

Prepared in cooperation with

VERMONT AGENCY OF TRANSPORTATION and

FEDERAL HIGHWAY ADMINISTRATION 


\section{LEVEL II SCOUR ANALYSIS FOR BRIDGE 25 (JAMATH00010025) on TOWN HIGHWAY 1, crossing BALL MOUNTAIN BROOK, JAMAICA, VERMONT \\ By Ronda L. Burns}

U.S. Geological Survey Open-File Report 97-376

Prepared in cooperation with

VERMONT AGENCY OF TRANSPORTATION and

FEDERAL HIGHWAY ADMINISTRATION 


\title{
U.S. DEPARTMENT OF THE INTERIOR BRUCE BABBITT, Secretary
}

\author{
U.S. GEOLOGICAL SURVEY \\ Gordon P. Eaton, Director
}

For additional information write to:

District Chief

U.S. Geological Survey 361 Commerce Way

Pembroke, NH 03275-3718
Copies of this report may be purchased from:

U.S. Geological Survey

Branch of Information Services

Open-File Reports Unit

Box 25286

Denver, CO 80225-0286 


\section{CONTENTS}

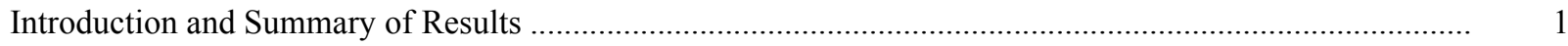

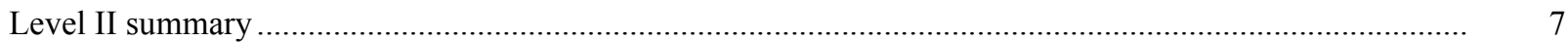

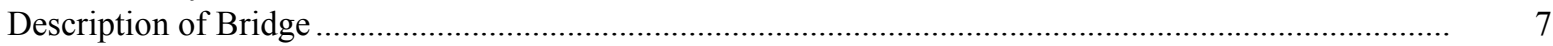

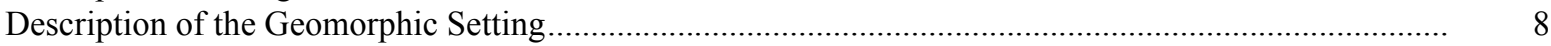

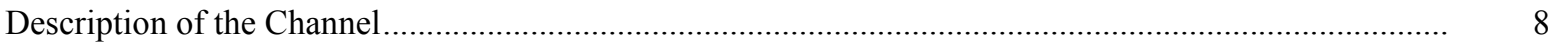

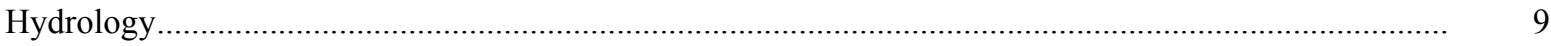

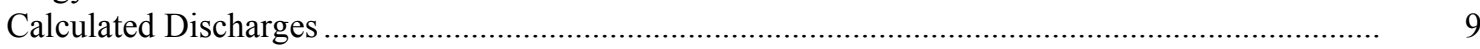

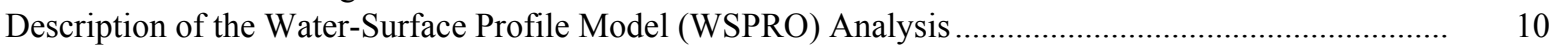

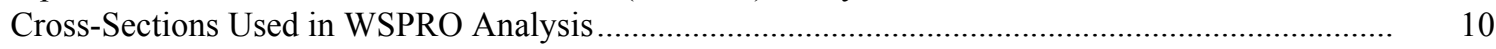

Data and Assumptions Used in WSPRO Model ...................................................................... 11

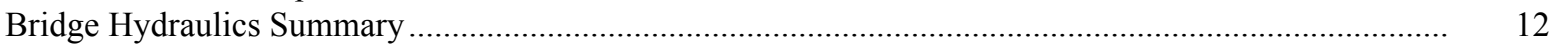

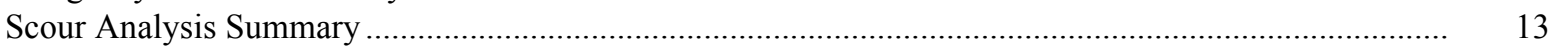

Special Conditions or Assumptions Made in Scour Analysis ...................................................... 13

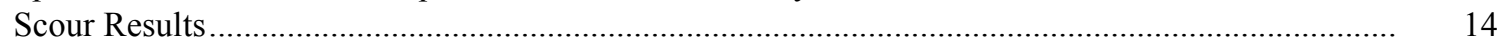

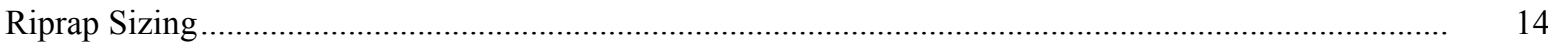

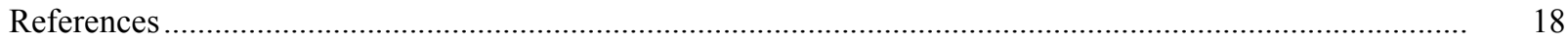

Appendixes:

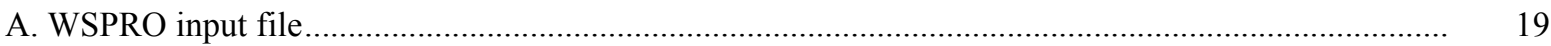

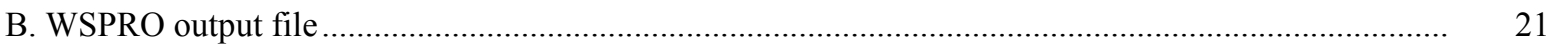

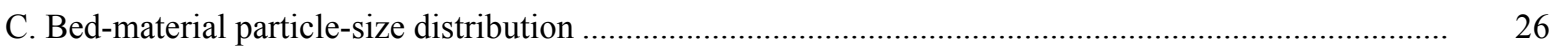

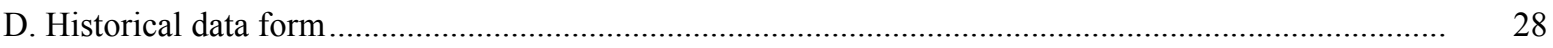

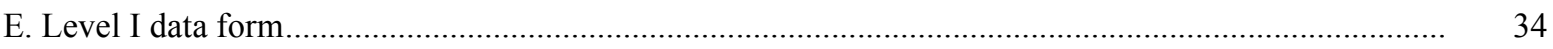

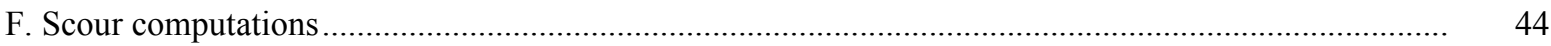

\section{FIGURES}

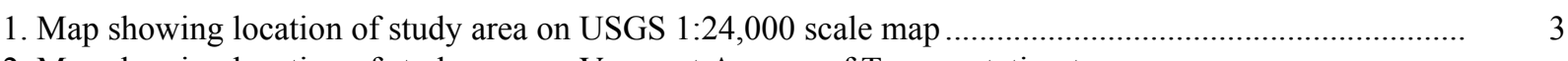

2. Map showing location of study area on Vermont Agency of Transportation town

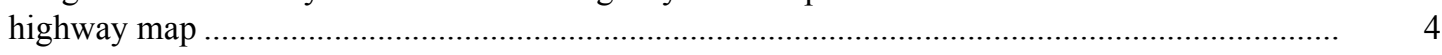

3. Structure JAMATH00010025 viewed from upstream (August 13, 1996)........................................... 5

4. Downstream channel viewed from structure JAMATH00010025 (August 13, 1996)............................ 5

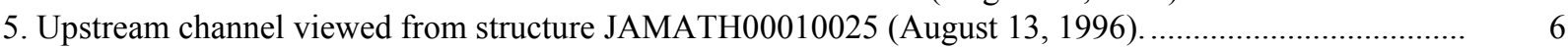

6. Structure JAMATH00010025 viewed from downstream (August 13, 1996)........................................ 6

7. Water-surface profiles for the 100- and 500-year discharges at structure JAMATH00010025 on Town Highway 1, crossing Ball Mountain Brook,

Jamaica, Vermont.

8. Scour elevations for the 100- and 500-year discharges at structure

JAMATH00010025 on Town Highway 1, crossing Ball Mountain Brook,

Jamaica, Vermont. 3

5

5

(1)

(1)

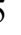

\section{TABLES}

1. Remaining footing/pile depth at abutments for the 100-year discharge at structure JAMATH00010025 on Town Highway 1, crossing Ball Mountain Brook,

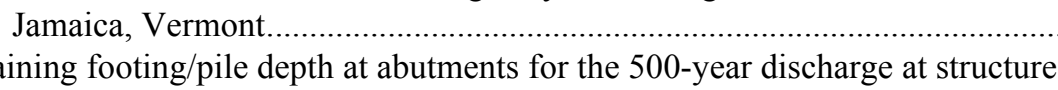
2. Remaining footing/pile depth at abutments for the 500-year discharge at structure
JAMATH00010025 on Town Highway 1, crossing Ball Mountain Brook, Jamaica, Vermont.. 


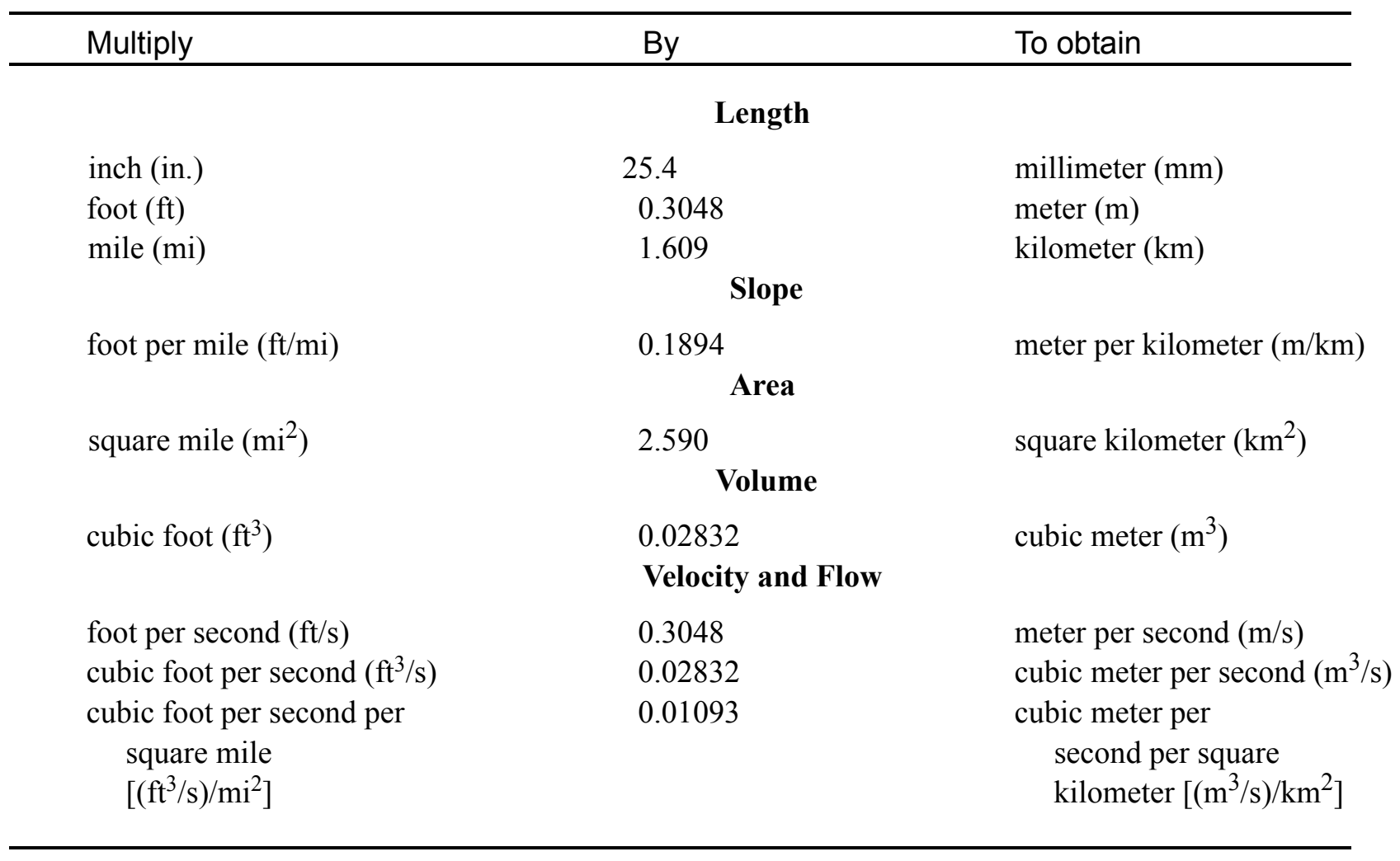

\section{OTHER ABBREVIATIONS}

$\begin{array}{lrlr}\mathrm{BF} & \text { bank full } & \text { LWW } & \text { left wingwall } \\ \mathrm{cfs} & \text { cubic feet per second } & \text { MC } & \text { main channel } \\ \mathrm{D}_{50} & \text { median diameter of bed material } & \text { RAB } & \text { right abutment } \\ \mathrm{DS} & \text { downstream } & \text { RABUT } & \text { face of right abutment } \\ \mathrm{elev} & \text { elevation } & \text { RB } & \text { right bank } \\ \mathrm{f} / \mathrm{p} & \text { flood plain } & \text { ROB } & \text { right overbank } \\ \mathrm{ft}^{2} & \text { square feet } & \text { RWW } & \text { right wingwall } \\ \mathrm{ft} / \mathrm{ft} & \text { feet per foot } & \text { TH } & \text { town highway } \\ \mathrm{JCT} & \text { junction } & \text { UB } & \text { under bridge } \\ \mathrm{LAB} & \text { left abutment } & \text { US } & \text { upstream } \\ \mathrm{LABUT} & \text { face of left abutment } & \text { USGS } & \text { United States Geological Survey } \\ \mathrm{LB} & \text { left bank } & \text { VTAOT Vermont Agency of Transportation } \\ \mathrm{LOB} & \text { left overbank } & \text { WSPRO } & \text { water-surface profile model }\end{array}$

In this report, the words "right" and "left" refer to directions that would be reported by an observer facing downstream. Sea level: In this report, "sea level" refers to the National Geodetic Vertical Datum of 1929-- a geodetic datum derived from a general adjustment of the first-order level nets of the United States and Canada, formerly called Sea Level Datum of 1929.

In the appendices, the above abbreviations may be combined. For example, USLB would represent upstream left bank. 


\title{
LEVEL II SCOUR ANALYSIS FOR BRIDGE 25 (JAMATH00010025) ON TOWN HIGHWAY 1, CROSSING BALL MOUNTAIN BROOK, JAMAICA, VERMONT
}

\author{
By Ronda L. Burns
}

\section{INTRODUCTION AND SUMMARY OF RESULTS}

This report provides the results of a detailed Level II analysis of scour potential at structure JAMATH00010025 on Town Highway 1 crossing Ball Mountain Brook, Jamaica, Vermont (figures 1-8). A Level II study is a basic engineering analysis of the site, including a quantitative analysis of stream stability and scour (U.S. Department of Transportation, 1993). Results of a Level I scour investigation also are included in Appendix E of this report. A Level I investigation provides a qualitative geomorphic characterization of the study site. Information on the bridge, gleaned from Vermont Agency of Transportation (VTAOT) files, was compiled prior to conducting Level I and Level II analyses and is found in Appendix D.

The site is in the Green Mountain section of the New England physiographic province in southern Vermont. The $29.5-\mathrm{mi}^{2}$ drainage area is in a predominantly rural and forested basin. In the vicinity of the study site, the surface cover is forest except on the downstream right bank which is pasture with some trees along the channel.

In the study area, Ball Mountain Brook has an incised, straight channel with a slope of approximately $0.021 \mathrm{ft} / \mathrm{ft}$, an average channel top width of $86 \mathrm{ft}$ and an average bank height of $9 \mathrm{ft}$. The channel bed material ranges from gravel to bedrock with a median grain size $\left(\mathrm{D}_{50}\right)$ of $222 \mathrm{~mm}(0.727 \mathrm{ft})$. The geomorphic assessment at the time of the Level I and Level II site visit on August 13, 1996, indicated that the reach was stable.

The Town Highway 1 crossing of Ball Mountain Brook is a 78-ft-long, two-lane bridge consisting of one 75-foot steel-beam span (Vermont Agency of Transportation, written communication, March 29, 1995). The opening length of the structure parallel to the bridge face is $73 \mathrm{ft}$. The bridge is supported by vertical, concrete abutments with wingwalls. The channel is skewed approximately 30 degrees to the opening while the opening-skew-toroadway is 30 degrees.

A scour hole $1.0 \mathrm{ft}$ deeper than the mean thalweg depth was observed at the upstream bridge face. The scour protection measures at the site were type- 2 stone fill (less than 36 inches diameter) along the upstream banks and along both abutments, and type- 3 stone fill (less than 48 inches diameter) along the downstream banks. Additional details describing conditions at the site are included in the Level II Summary and Appendices D and E. 
Scour depths and recommended rock rip-rap sizes were computed using the general guidelines described in Hydraulic Engineering Circular 18 (Richardson and others, 1995). Total scour at a highway crossing is comprised of three components: 1) long-term streambed degradation; 2) contraction scour (due to accelerated flow caused by a reduction in flow area at a bridge) and; 3) local scour (caused by accelerated flow around piers and abutments). Total scour is the sum of the three components. Equations are available to compute depths for contraction and local scour and a summary of the results of these computations follows.

Contraction scour only occurred at the 500-year discharge and was $0.1 \mathrm{ft}$. Abutment scour ranged from 11.2 to $15.7 \mathrm{ft}$. The worst-case abutment scour occurred at the 500 -year discharge. Additional information on scour depths and depths to armoring are included in the section titled "Scour Results". Scoured-streambed elevations, based on the calculated scour depths, are presented in tables 1 and 2. A cross-section of the scour computed at the bridge is presented in figure 8 . Scour depths were calculated assuming an infinite depth of erosive material and a homogeneous particle-size distribution.

It is generally accepted that the Froehlich equation (abutment scour) gives "excessively conservative estimates of scour depths" (Richardson and others, 1995, p. 47). Usually, computed scour depths are evaluated in combination with other information including (but not limited to) historical performance during flood events, the geomorphic stability assessment, existing scour protection measures, and the results of the hydraulic analyses. Therefore, scour depths adopted by VTAOT may differ from the computed values documented herein. 


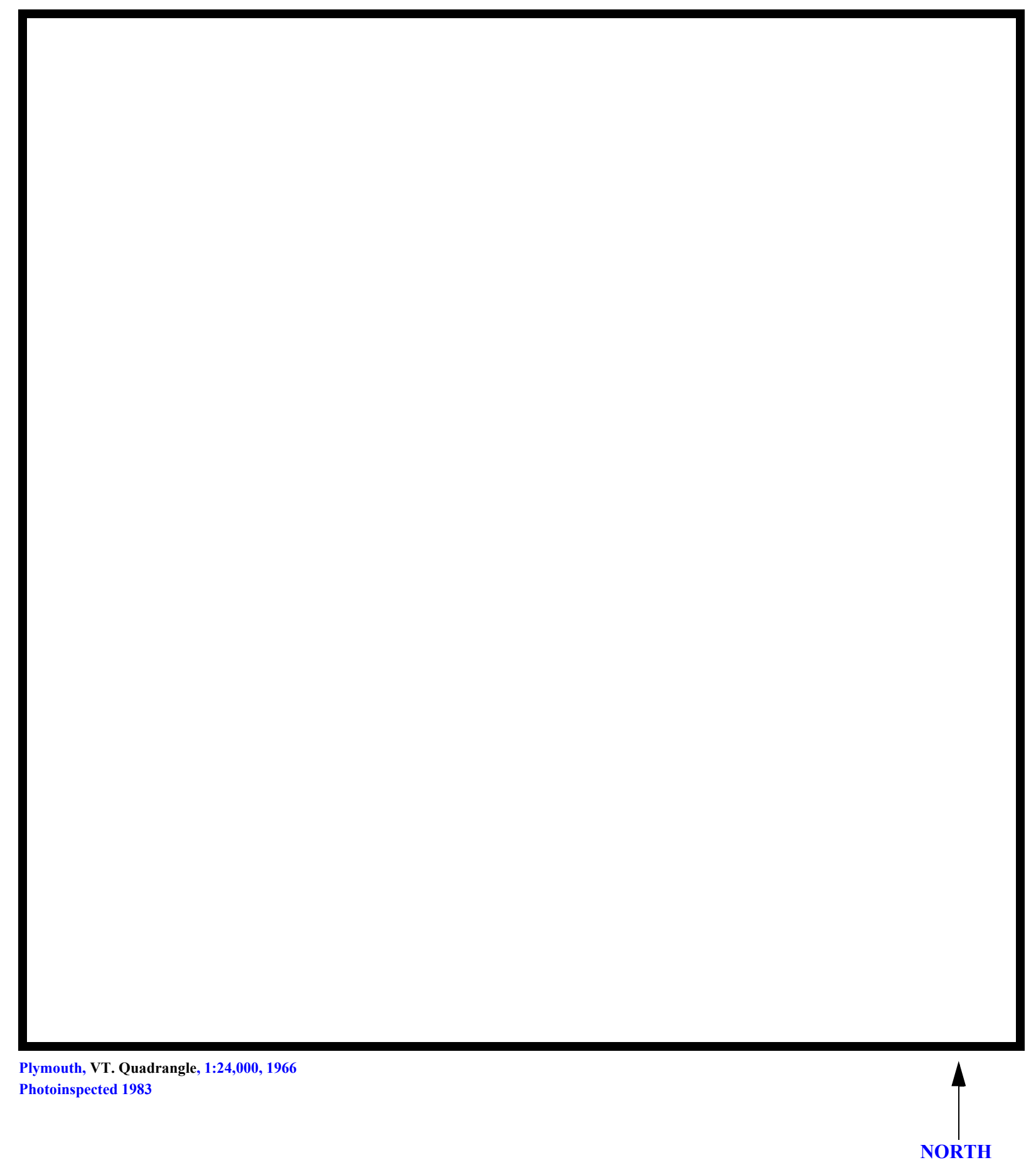

Figure 1. Location of study area on USGS 1:24,000 scale map. 
Figure 2. Location of study area on Vermont Agency of Transportation town highway map. 

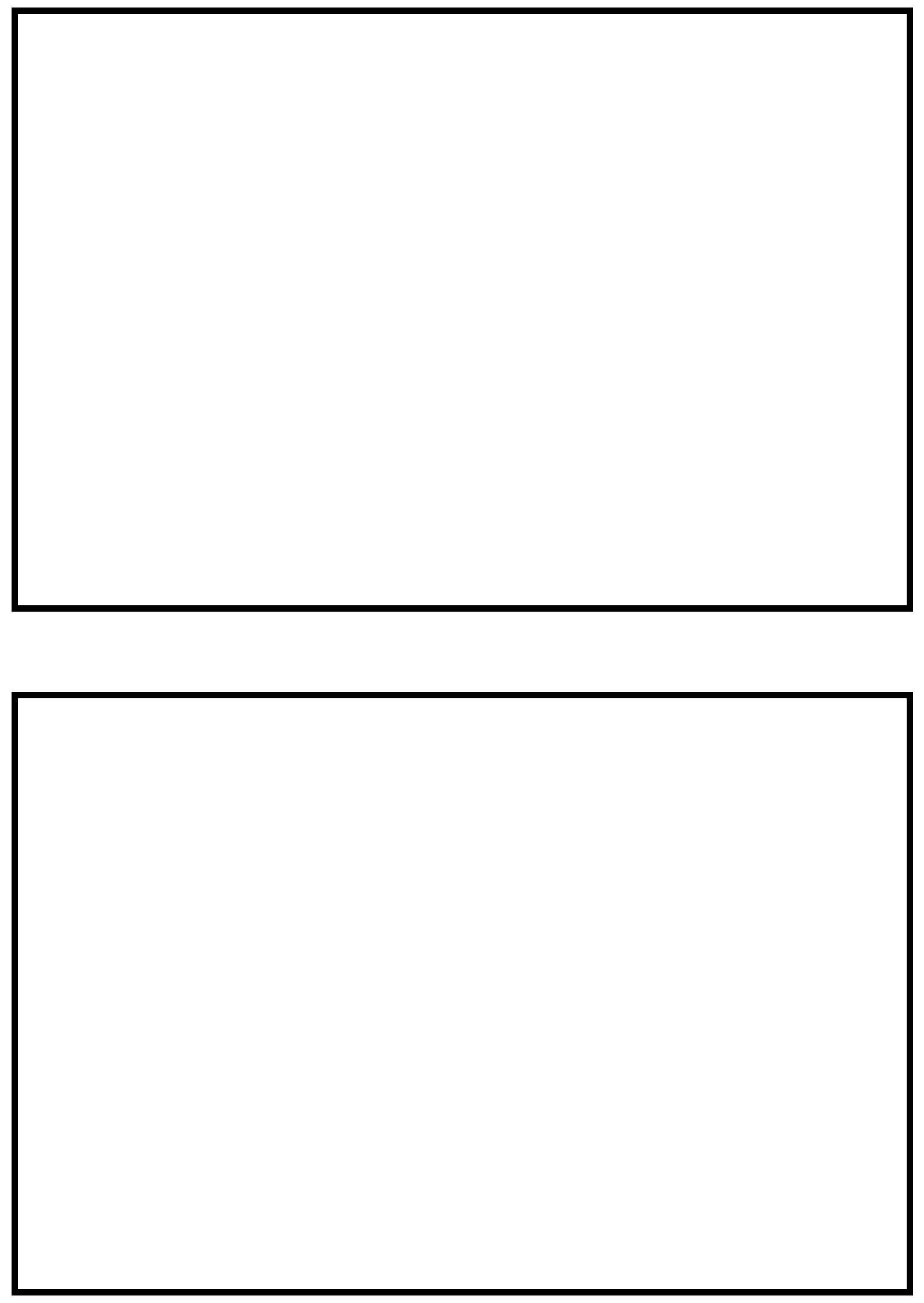

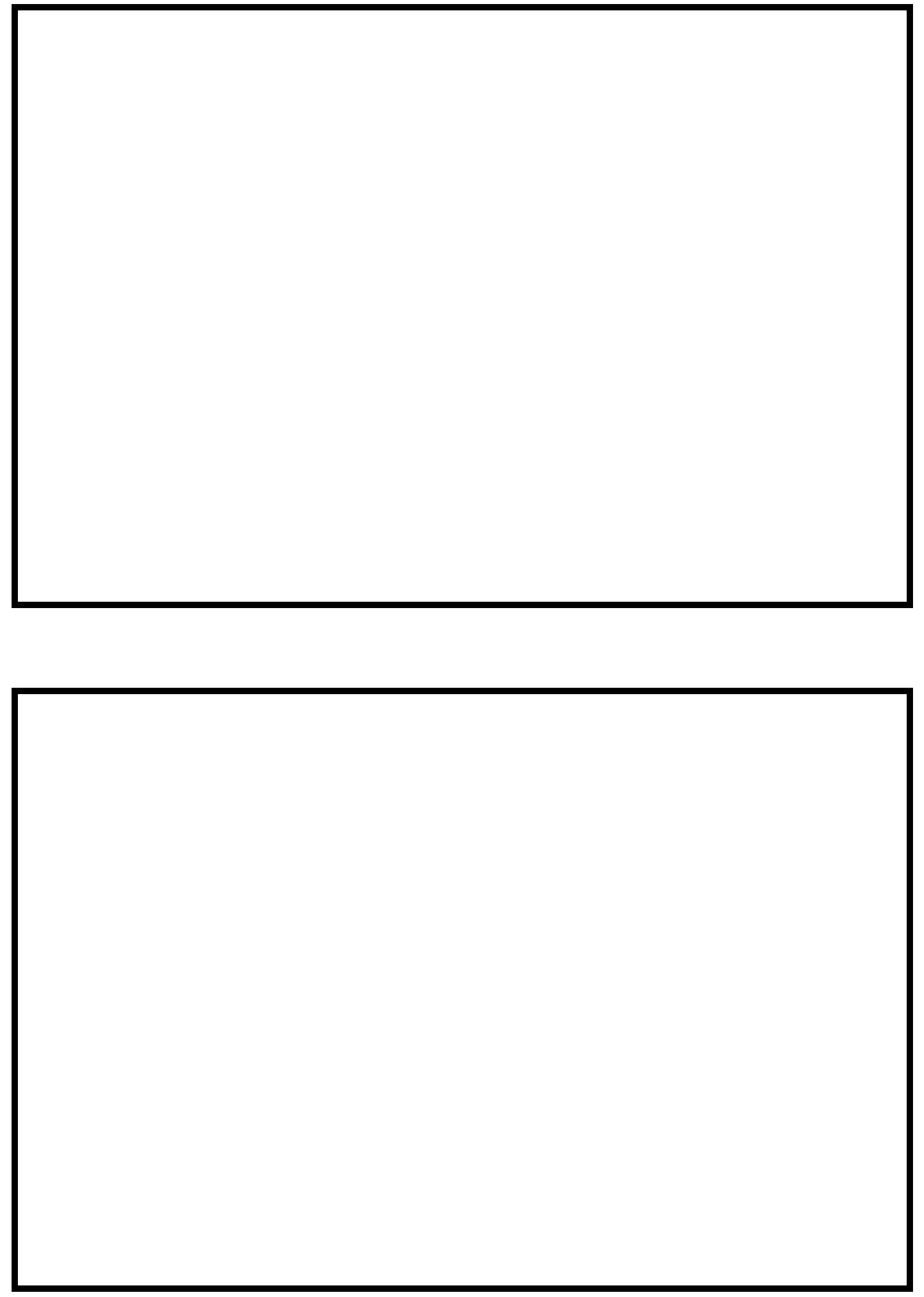


\section{LEVEL II SUMMARY}

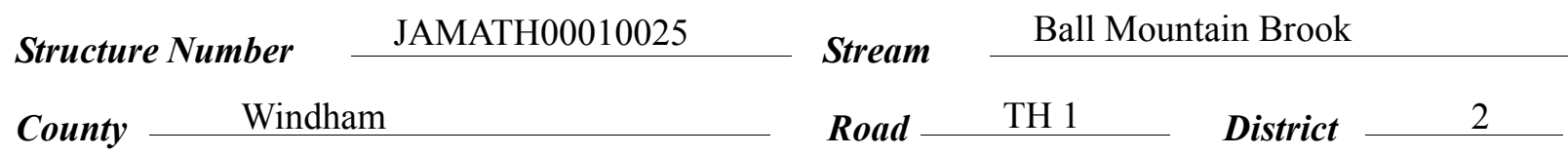

\section{Description of Bridge}

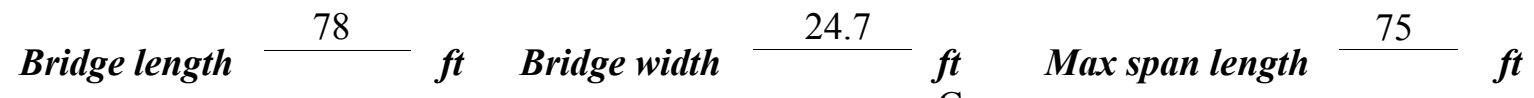
Alignment of bridge to road (on curve or straight)

\section{Abutment type}

Stone fill on abutment? Vertical, concrete

nasninintin.. af atoms sill $\mathrm{Y}$

\section{Embankment type} Curve along all of the wingwalls.

\section{Sloping}

08/13/96

\section{along all of the wingwalls.}

Dato of insmortinn
Type-2, along the entire length of the left and right abutments and

$\ldots \ldots \ldots$

Abutments and wingwalls are concrete.

\begin{tabular}{|c|c|c|c|}
\hline & & $\mathrm{Y}$ & 30 \\
\hline Is bridge skewed to flood flow according to $\mathrm{N}$ & ' survey? & \multicolumn{2}{|c|}{ Angle } \\
\hline
\end{tabular}

Debris accumulation on bridge at time of Level I or Level II site visit:

\begin{tabular}{|c|c|c|c|}
\hline & $\begin{array}{c}\text { Date of insnortion } \\
08 / 13 / 96 \\
\end{array}$ & $\begin{array}{l}\text { Percent of ofmonal } \\
\text { blocked hortzontatly }\end{array}$ & $\begin{array}{l}\text { Percent of } 0 \\
\text { blocked verticatty }\end{array}$ \\
\hline Level I & $08 / 13 / 96$ & 0 & 0 \\
\hline
\end{tabular}

Level II

Moderate. There is some debris caught on the stone fill in front of the upstream and downstream left wingwalls.

Potential for debris

None 08/13/96.

Dosrriho anv fonturos noar ar at tho hridoo that mav affort flow, (includo ahsoryation dato) 


\section{Description of the Geomorphic Setting}

General topography The channel is located in a moderate relief valley setting.

Geomorphic conditions at bridge site: downstream (DS), upstream (US)

Date of inspection $\quad 08 / 13 / 96$

DS left: $\quad$ Steep valley wall

DS right: $\quad$ Steep channel bank to a moderately sloped overbank

US left: $\quad$ Steep valley wall

US right: Steep channel bank to a moderately sloped overbank

\section{Description of the Channel}

$\begin{array}{llll}\text { Average top width } & 86 & \text { Average depth } & 9 \\ & \text { Cobbles/Boulders } & \text { Cobbles/Boulders }\end{array}$

Predominant bed material

Bank material Straight and stable

with semi-allúvial channel boundaries.

$08 / 13 / 96$

Vegetative co $1^{1}$ Trees

DS left: $\quad$ Some trees and brush with short grass on the overbank

DS right: Trees

US left: $\quad$ Trees, brush and grass

US right: $\quad \underline{\mathrm{Y}}$

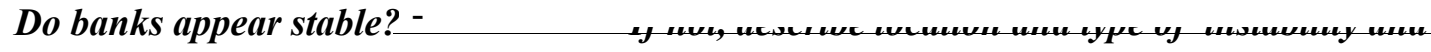

date of observation.

None $08 / 13 / 96$.

Describe any obstructions in channel and date of observation. 


\section{Hydrology}

Drainage area $\quad 29.5 \quad \mathrm{mi}^{2}$

Percentage of drainage area in physiographic provinces: (approximate)

Physiographic province/section

New England/Green Mountain
Percent of drainage area 100

Is drainage area considered rural or urban? — Rural _ Describe any significant urbanization:

Is there a USGS gage on the stream of interest?

$\mathrm{N}$

USGS gage description

USGS gage number

Gage drainage area $\mathrm{mi}^{2}$

Is there a lake/p

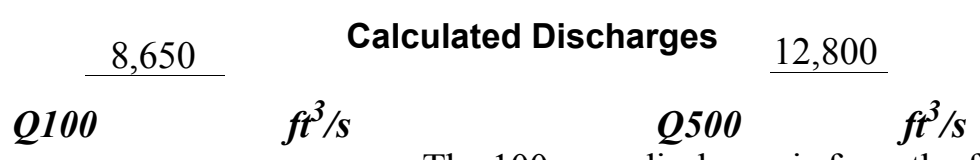

The 100-year discharge is from the flood frequency

estimates available from the VTAOT database. The 500-year event was extrapolated from these estimates. The values used were within a range defined by flood frequency curves developed from several empirical methods (Benson, 1962; Johnson and Tasker, 1974; FHWA, 1983; Potter, 1957a\&b; Talbot, 1887) 


\section{Description of the Water-Surface Profile Model (WSPRO) Analysis}

Datum for WSPRO analysis (USGS survey, sea level, VTAOT plans)

USGS survey

Datum tie between USGS survey and VTAOT plans

Subtract $4.9 \mathrm{ft}$. from the USGS

arbitrary survey datum to obtain the VTAOT plans' datum.

Description of reference marks used to determine USGS datum. $\quad$ RM1 is a VTAOT

survey disk on top of the upstream end of the left abutment (elev. $498.66 \mathrm{ft}$, arbitrary survey

datum). RM2 is a chiseled $\mathrm{X}$ inside a pre-existing chiseled square on top of the upstream end of

the right abutment (elev. $499.52 \mathrm{ft}$, arbitrary survey datum).

\section{Cross-Sections Used in WSPRO Analysis}

\begin{tabular}{|c|c|c|c|}
\hline${ }^{1}$ Cross-section & $\begin{array}{c}\text { Section } \\
\text { Reference } \\
\text { Distance } \\
\text { (SRD) in feet }\end{array}$ & $\begin{array}{c}{ }^{2} \text { Cross-section } \\
\text { development }\end{array}$ & Comments \\
\hline EXIT1 & -98 & 1 & Exit section \\
\hline FULLV & 0 & 2 & $\begin{array}{l}\text { Downstream Full-valley } \\
\text { section (Templated from } \\
\text { EXIT1) }\end{array}$ \\
\hline BRIDG & 0 & 1 & Bridge section \\
\hline RDWAY & 16 & 1 & Road Grade section \\
\hline APPRO & 95 & 2 & $\begin{array}{l}\text { Modelled Approach sec- } \\
\text { tion (Templated from } \\
\text { APTEM) }\end{array}$ \\
\hline APTEM & 98 & 1 & $\begin{array}{l}\text { Approach section as sur- } \\
\text { veyed (Used as a tem- } \\
\text { plate) }\end{array}$ \\
\hline
\end{tabular}

${ }^{1}$ For location of cross-sections see plan-view sketch included with Level I field form, Appendix E. For more detail on how cross-sections were developed see WSPRO input file. 


\section{Data and Assumptions Used in WSPRO Model}

Hydraulic analyses of the reach were done by use of the Federal Highway Administration's WSPRO step-backwater computer program (Shearman and others, 1986, and Shearman, 1990). The analyses reported herein reflect conditions existing at the site at the time of the study. Furthermore, in the development of the model it was necessary to assume no accumulation of debris or ice at the site. Results of the hydraulic model are presented in the Bridge Hydraulic Summary, Appendix B, and figure 7.

Channel roughness factors (Manning's " $n$ ") used in the hydraulic model were estimated using field inspections at each cross section following the general guidelines described by Arcement and Schneider (1989). Final adjustments to the values were made during the modelling of the reach. Channel " $\mathrm{n}$ " values for the reach ranged from 0.050 to 0.065 , and overbank " $n$ " values ranged from 0.060 to 0.080 .

Normal depth at the exit section (EXIT1) was assumed as the starting water surface. This depth was computed by use of the slope-conveyance method outlined in the user's manual for WSPRO (Shearman, 1990). The slope used was $0.021 \mathrm{ft} / \mathrm{ft}$ which was estimated from the streambed slope downstream of the bridge in the Flood Insurance Study for Jamaica, VT (Federal Emergency Management Agency, May 17, 1988).

The surveyed approach section (APTEM) was moved along the approach channel slope $(0.048 \mathrm{ft} / \mathrm{ft})$ to establish the modelled approach section (APPRO), one bridge length upstream of the upstream face as recommended by Shearman and others (1986). This location also provides a consistent method for determining scour variables. 


\section{Bridge Hydraulics Summary}

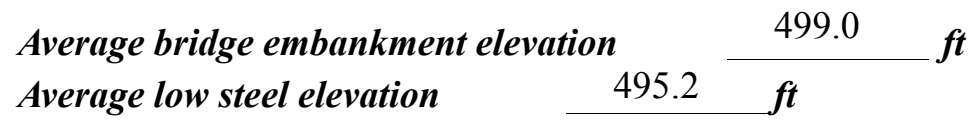

$$
\text { 100-year discharge } \quad 8,650 \quad \mathrm{ft}^{3} / \mathrm{s}
$$

Water-surface elevation in bridge opening $\quad 492.1 \quad f t$

Road overtopping? ___ N Discharge over road ___ - $\mathrm{ft}^{3} / \mathrm{s}$

Area of flow in bridge opening $\quad 675 \quad \mathrm{ft}^{2}$

Average velocity in bridge opening $12.8 \quad \mathrm{ft} / \mathrm{s}$

Maximum WSPRO tube velocity at bridge $15.8 \mathrm{ft} / \mathrm{s}$

Water-surface elevation at Approach section with bridge 493.9

$\begin{array}{ll}\text { Water-surface elevation at Approach section without bridge } & 493.7\end{array}$

Amount of backwater caused by bridge $\quad 0.2$ it

500-year discharge $\quad 12,800 \quad \boldsymbol{f t}^{3} / \mathrm{s}$

Water-surface elevation in bridge opening

$492.9 \boldsymbol{f t}$

Road overtopping? ___ N Discharge over road ___ - ${ }_{2} i^{3} / \mathrm{s}$

Area of flow in bridge opening $\quad 722 \quad \mathrm{ft}^{2}$

Average velocity in bridge opening $\quad 17.7 \mathrm{ft} / \mathrm{s}$

Maximum WSPRO tube velocity at bridge 22.0 _s

Water-surface elevation at Approach section with bridge 496.5

Water-surface elevation at Approach section without bridge $\quad 496.5$

Amount of backwater caused by bridge $\quad 0.0$.t

Incipient overtopping discharge ___ _ $\quad f^{3} / \mathrm{s}$

Water-surface elevation in bridge opening $\quad-\quad t$

Area of flow in bridge opening _ _ _ $\mathrm{ft}^{2}$

Average velocity in bridge opening ___ $\quad \mathrm{ft} / \mathrm{s}$

Maximum WSPRO tube velocity at bridge $\quad-\quad \mathrm{ft} / \mathrm{s}$

Water-surface elevation at Approach section with bridge

Water-surface elevation at Approach section without bridge

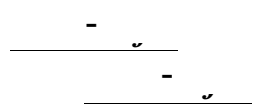

Amount of backwater caused by bridge _ _ _ t 


\section{Scour Analysis Summary}

\section{Special Conditions or Assumptions Made in Scour Analysis}

Scour depths were computed using the general guidelines described in Hydraulic Engineering Circular 18 (Richardson and others, 1995). Scour depths were calculated assuming an infinite depth of erosive material and a homogeneous particle-size distribution. The results of the scour analysis are presented in tables 1 and 2 and a graph of the scour depths is presented in figure 8 .

Contraction scour for the 100-year and 500-year discharges was computed by use of both the clear-water and live-bed contraction scour equations (Richardson and others, 1995, p. 30, equation 17 and p. 32, equation 20) since the average channel velocity and the incipient-motion velocity of the bed material are nearly the same. Because coarse bedmaterial is present, the smaller of the computed contraction scour results for each discharge was selected as recommended (Richardson and others, 1995, p. 31). Hence, results from the live-bed contraction scour equation are shown for the 500-year discharge and results from the clear-water contraction scour equation are shown for the 100-year discharge. Results of this analysis are presented in figure 8 and tables 1 and 2. The results of Laursen's live-bed and clear-water contraction scour are also provided in appendix F.

Abutment scour for both abutments was computed by use of the Froehlich equation (Richardson and others, 1995, p. 48, equation 28). Variables for the Froehlich equation include the Froude number of the flow approaching the embankments, the length of the embankment blocking flow, and the depth of flow approaching the embankment less any roadway overtopping. The left abutment scour may be limited by the bedrock noted on the left bank. 


\section{Scour Results}

100-yr discharge 500-yr discharge

Incipient

Contraction scour:

(Scour depths in feet)

Main channel

Live-bed scour

Clear-water scour

Depth to armoring

Left overbank

Right overbank
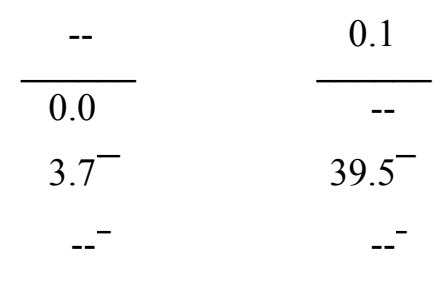

$39.5^{-}$

overtopping

discharge

Local scour:

Abutment scour

Left abutment

11.2

14.9

$13.5-$

$15.7-$

Right abutment

Pier scour

Pier 1

Pier 2

Pier 3

Abutments:

Left abutment

Right abutment

Piers:

Pier 1

Pier 2

\section{Riprap Sizing}

Incipient overtopping 100-yr discharge 500-yrdischarge discharge

3.2

3.2

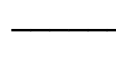

$--$

$--$

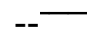
( $D_{50}$ in feet)

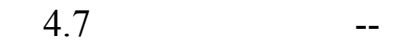

4.7
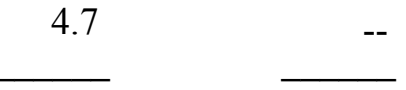

$-{ }^{-}$

$-{ }^{-}$

$--$

$--$ 


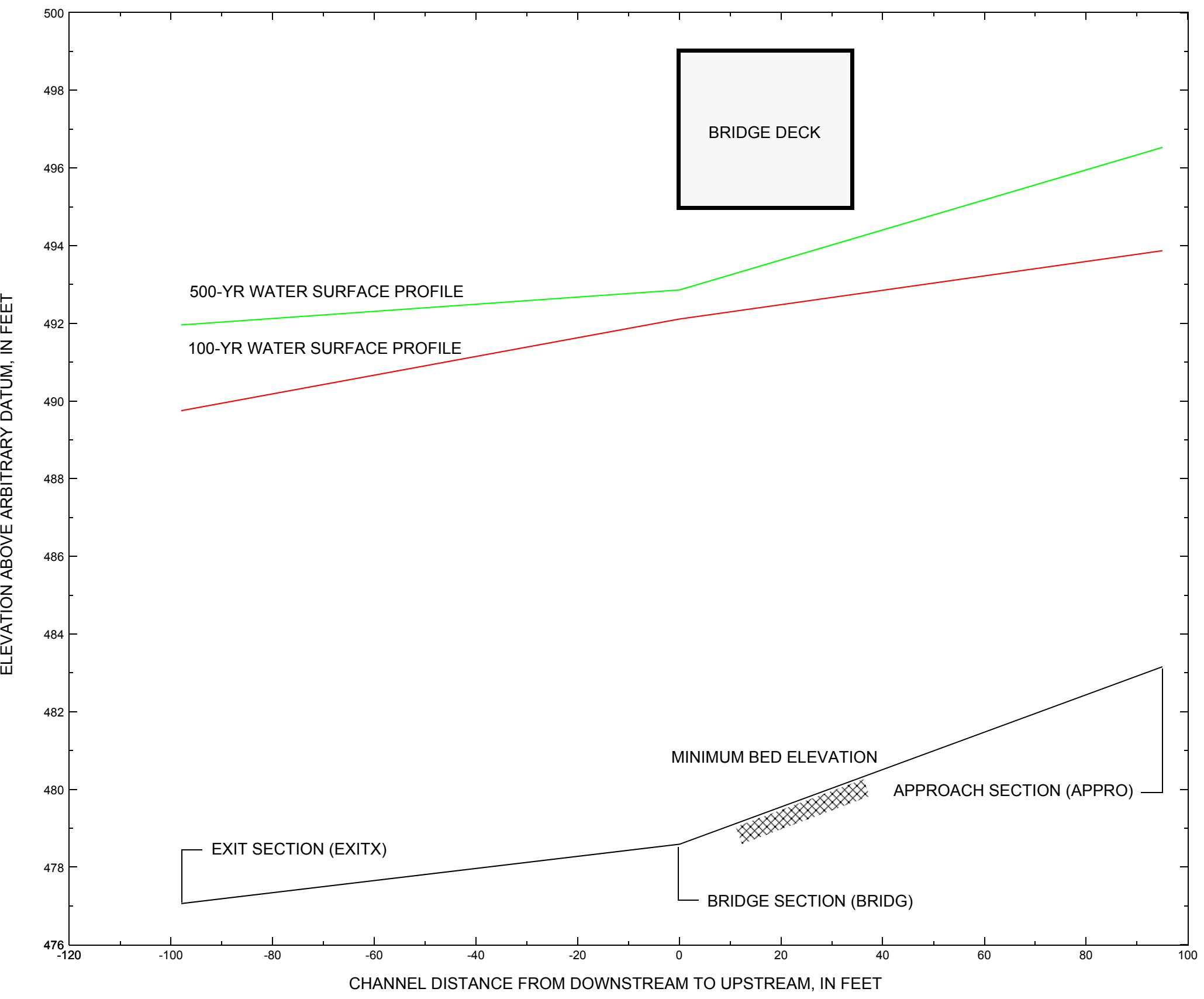

Figure 7. Water-surface profiles for the 100- and 500-yr discharges at structure JAMATH00010025 on Town Highway 1, crossing Ball Mountain Brook, Jamaica, Vermont. 


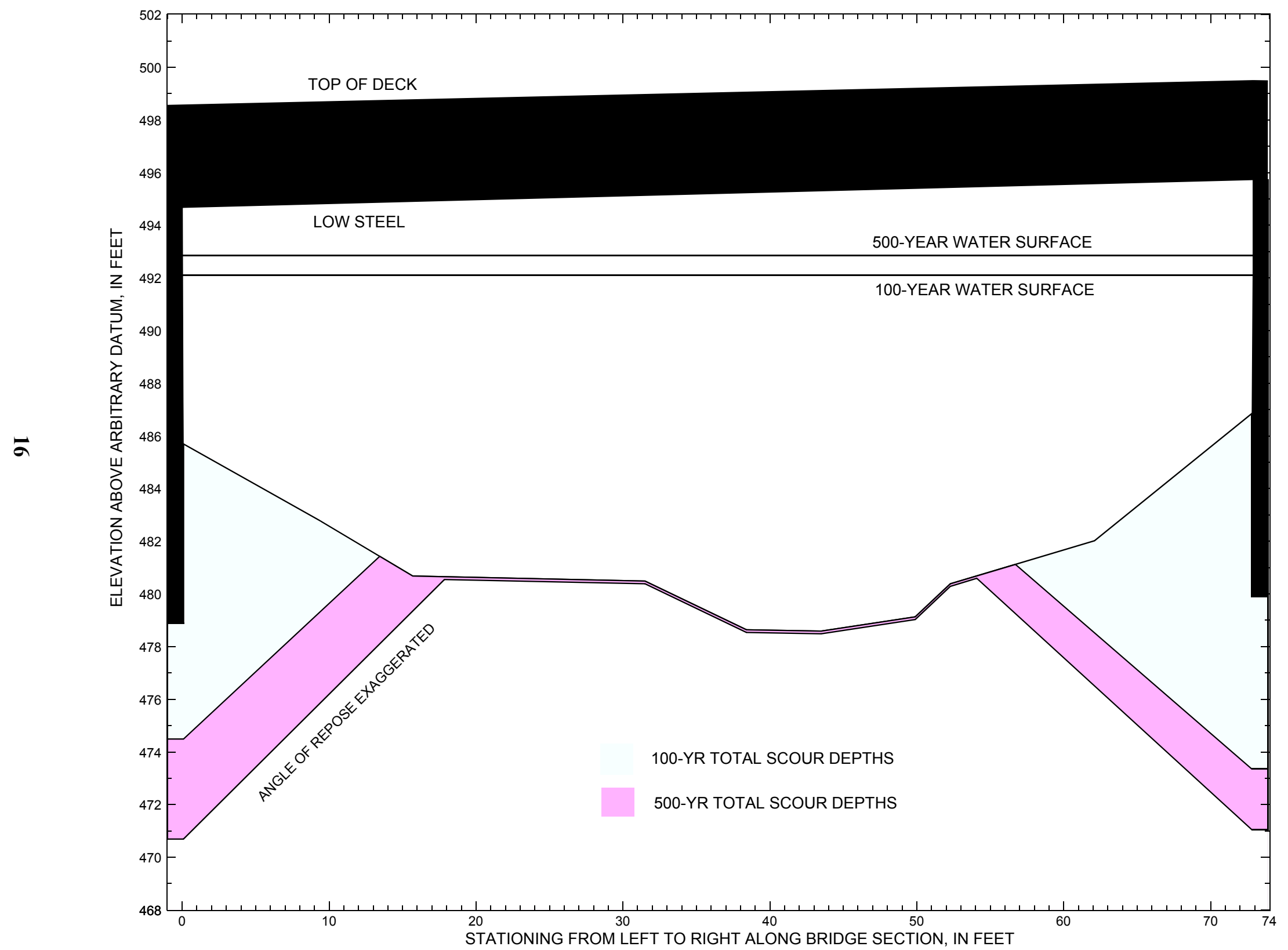

Figure 8. Scour elevations for the 100-yr and 500-yr discharges at structure JAMATH00010025 on Town Highway 1, crossing Ball Mountain Brook, Jamaica, Vermont. 
Table 1. Remaining footing/pile depth at abutments for the 100-year discharge at structure JAMATH00010025 on Town Highway 1, crossing Ball Mountain Brook, Jamaica, Vermont.

[VTAOT, Vermont Agency of Transportation; --, no data]

\begin{tabular}{|c|c|c|c|c|c|c|c|c|c|c|c|}
\hline Description & Station $^{1}$ & $\begin{array}{c}\text { VTAOT } \\
\text { bridge seat } \\
\text { elevation } \\
\text { (feet) }\end{array}$ & $\begin{array}{l}\text { Surveyed } \\
\text { minimum } \\
\text { low-chord } \\
\text { elevation } \\
\quad \text { (feet) }\end{array}$ & $\begin{array}{l}\text { Bottom of } \\
\text { footing } \\
\text { elevation } \\
\text { (feet) }\end{array}$ & $\begin{array}{c}\text { Channel } \\
\text { elevation at } \\
\text { abutment/ } \\
\text { pier }^{2} \\
\text { (feet) }\end{array}$ & $\begin{array}{l}\text { Contraction } \\
\text { scour depth } \\
\text { (feet) }\end{array}$ & $\begin{array}{l}\text { Abutment } \\
\text { scour } \\
\text { depth } \\
\text { (feet) }\end{array}$ & $\begin{array}{l}\text { Pier } \\
\text { scour } \\
\text { depth } \\
\text { (feet) }\end{array}$ & $\begin{array}{l}\text { Depth of } \\
\text { total scour } \\
\text { (feet) }\end{array}$ & $\begin{array}{c}\text { Elevation of } \\
\text { scour }^{2} \\
\text { (feet) }\end{array}$ & $\begin{array}{l}\text { Remaining } \\
\text { footing/pile } \\
\text { depth } \\
\text { (feet) }\end{array}$ \\
\hline \multicolumn{12}{|c|}{100 -yr. discharge is 8,650 cubic-feet per second } \\
\hline Left abutment & 0.0 & 489.6 & 494.7 & 478.9 & 485.7 & 0.0 & 11.2 & -- & 11.2 & 474.5 & -4.4 \\
\hline Right abutment & 72.9 & 490.7 & 495.7 & 479.9 & 486.9 & 0.0 & 13.5 & -- & 13.5 & 473.4 & -6.5 \\
\hline
\end{tabular}

1.Measured along the face of the most constricting side of the bridge.

2.Arbitrary datum for this study.

Table 2. Remaining footing/pile depth at abutments for the 500-year discharge at structure JAMATH00010025 on Town Highway 1, crossing Ball Mountain Brook, Jamaica, Vermont.

[VTAOT, Vermont Agency of Transportation; --, no data]

\begin{tabular}{|c|c|c|c|c|c|c|c|c|c|c|c|}
\hline Description & Station ${ }^{1}$ & $\begin{array}{l}\text { VTAOT } \\
\text { bridge seat } \\
\text { elevation } \\
\text { (feet) }\end{array}$ & $\begin{array}{c}\text { Surveyed } \\
\text { minimum } \\
\text { low-chord } \\
\text { elevation }{ }^{2} \\
\text { (feet) }\end{array}$ & $\begin{array}{c}\text { Bottom of } \\
\text { footing } \\
\text { elevation } \\
\text { (feet) }\end{array}$ & $\begin{array}{c}\text { Channel } \\
\text { elevation at } \\
\text { abutment/ } \\
\text { pier }^{2} \\
\text { (feet) }\end{array}$ & $\begin{array}{l}\text { Contraction } \\
\text { scour depth } \\
\text { (feet) }\end{array}$ & $\begin{array}{l}\text { Abutment } \\
\text { scour } \\
\text { depth } \\
\text { (feet) }\end{array}$ & $\begin{array}{l}\text { Pier } \\
\text { scour } \\
\text { depth } \\
\text { (feet) }\end{array}$ & $\begin{array}{l}\text { Depth of } \\
\text { total scour } \\
\text { (feet) }\end{array}$ & $\begin{array}{c}\text { Elevation of } \\
\text { scour }^{2} \\
\text { (feet) }\end{array}$ & $\begin{array}{c}\text { Remaining } \\
\text { footing/pile } \\
\text { depth } \\
\text { (feet) }\end{array}$ \\
\hline \multicolumn{12}{|c|}{500 -yr. discharge is 12,800 cubic-feet per second } \\
\hline Left abutment & 0.0 & 489.6 & 494.7 & 478.9 & 485.7 & 0.1 & 14.9 & -- & 15.0 & 470.7 & -8.2 \\
\hline Right abutment & 72.9 & 490.7 & 495.7 & 479.9 & 486.9 & 0.1 & 15.7 & -- & 15.8 & 471.1 & -8.8 \\
\hline
\end{tabular}

1.Measured along the face of the most constricting side of the bridge.

2.Arbitrary datum for this study. 


\section{SELECTED REFERENCES}

Arcement, G.J., Jr., and Schneider, V.R., 1989, Guide for selecting Manning's roughness coefficients for natural channels and flood plains:

U.S. Geological Survey Water-Supply Paper 2339, 38 p.

Barnes, H.H., Jr., 1967, Roughness characteristics of natural channels: U.S. Geological Survey Water-Supply Paper 1849,213 p.

Benson, M. A., 1962, Factors Influencing the Occurrence of Floods in a Humid Region of Diverse Terrain: U.S. Geological Survey WaterSupply Paper 1580-B, 64 p.

Brown, S.A. and Clyde, E.S., 1989, Design of riprap revetment: Federal Highway Administration Hydraulic Engineering Circular No. 11, Publication FHWA-IP-89-016, 156 p.

Federal Highway Administration, 1983, Runoff estimates for small watersheds and development of sound design: Federal Highway Administration Report FHWA-RD-77-158.

Federal Highway Administration, 1993, Stream Stability and Scour at Highway Bridges: Participant Workbook: Federal Highway Administration Report FHWA-HI-91-011.

Federal Emergency Management Agency, 1988, Flood Insurance Study, Town of Jamaica, Windham County, Vermont: Washington, D.C., May 171988.

Froehlich, D.C., 1989, Local scour at bridge abutments in Ports, M.A., ed., Hydraulic Engineering--Proceedings of the 1989 National Conference on Hydraulic Engineering: New York, American Society of Civil Engineers, p. 13-18.

Hayes, D.C.,1993, Site selection and collection of bridge-scour data in Delaware, Maryland, and Virginia: U.S. Geological Survey WaterResources Investigation Report 93-4017, 23 p.

Johnson, C.G. and Tasker, G.D.,1974, Progress report on flood magnitude and frequency of Vermont streams: U.S. Geological Survey OpenFile Report 74-130, 37 p.

Lagasse, P.F., Schall, J.D., Johnson, F., Richardson, E.V., Chang, F., 1995, Stream Stability at Highway Structures: Federal Highway Administration Hydraulic Engineering Circular No. 20, Publication FHWA-IP-90-014, 144 p.

Laursen, E.M., 1960, Scour at bridge crossings: Journal of the Hydraulics Division, American Society of Civil Engineers, v. 86, no. HY2, p. 39-53.

Potter, W. D., 1957a, Peak rates of runoff in the Adirondack, White Mountains, and Maine woods area, Bureau of Public Roads

Potter, W. D., 1957b, Peak rates of runoff in the New England Hill and Lowland area, Bureau of Public Roads

Richardson, E.V. and Davis, S.R., 1995, Evaluating scour at bridges: Federal Highway Administration Hydraulic Engineering Circular No. 18, Publication FHWA-IP-90-017, 204 p.

Richardson, E.V., Simons, D.B., and Julien, P.Y., 1990, Highways in the river environment: Federal Highway Administration Publication FHWA-HI-90-016.

Ritter, D.F., 1984, Process Geomorphology: W.C. Brown Co., Debuque, Iowa, 603 p.

Shearman, J.O., 1990, User's manual for WSPRO--a computer model for water surface profile computations: Federal Highway Administration Publication FHWA-IP-89-027, 187 p.

Shearman, J.O., Kirby, W.H., Schneider, V.R., and Flippo, H.N., 1986, Bridge waterways analysis model; research report: Federal Highway Administration Publication FHWA-RD-86-108, 112 p.

Talbot, A.N., 1887, The determination of water-way for bridges and culverts.

U.S. Department of Transportation, 1993, Stream stability and scour at highway bridges, Participant Workbook: Federal Highway Administration Publication FHWA HI-91-011.

U.S. Geological Survey, 1986, Jamaica, Vermont 7.5 Minute Series quadrangle map: U.S. Geological Survey Topographic Maps, Scale $1: 24,000$. 


\section{APPENDIX A: \\ WSPRO INPUT FILE}




\section{WSPRO INPUT FILE}

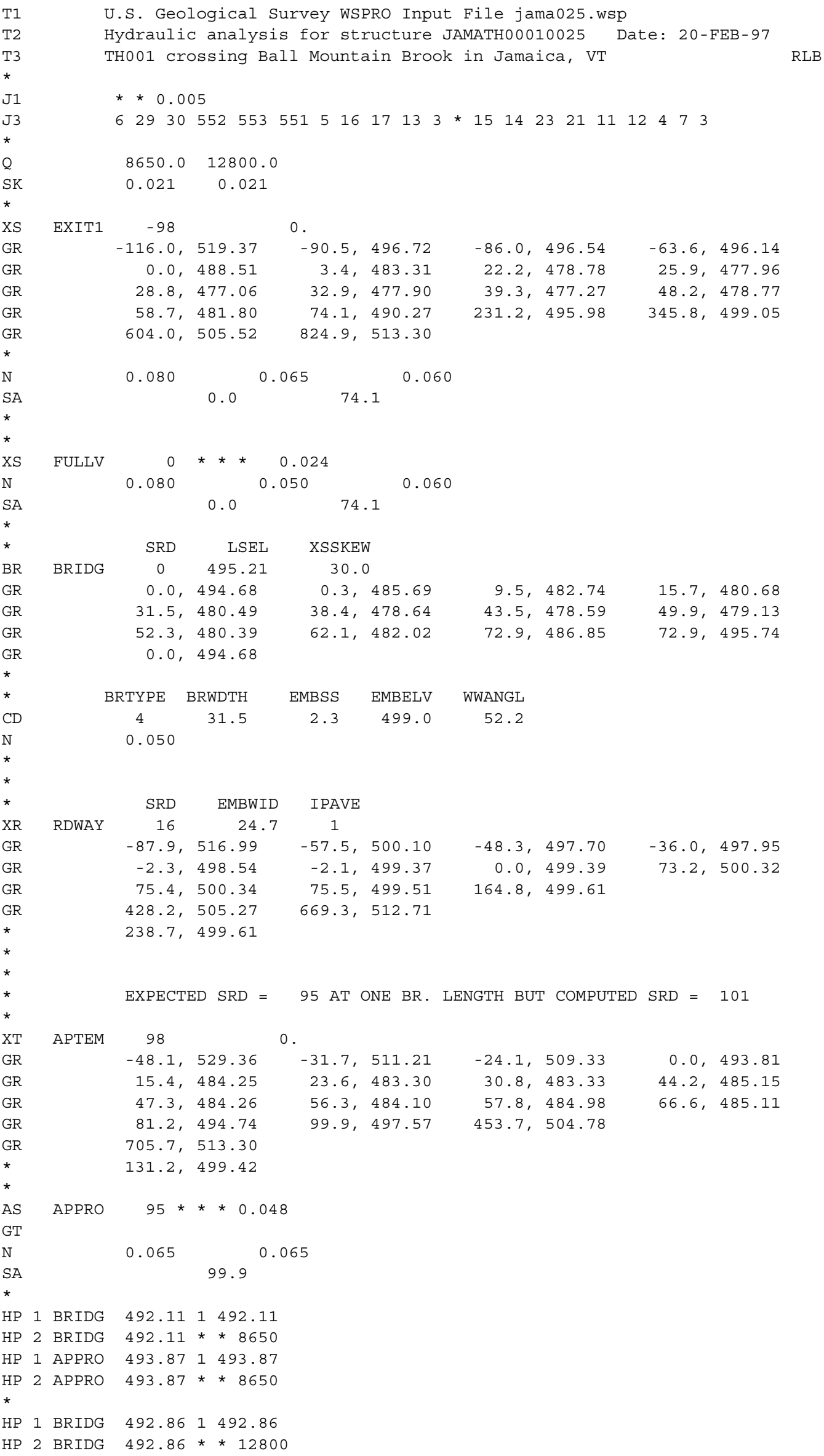




\section{APPENDIX B: \\ WSPRO OUTPUT FILE}


WSPRO OUTPUT FILE

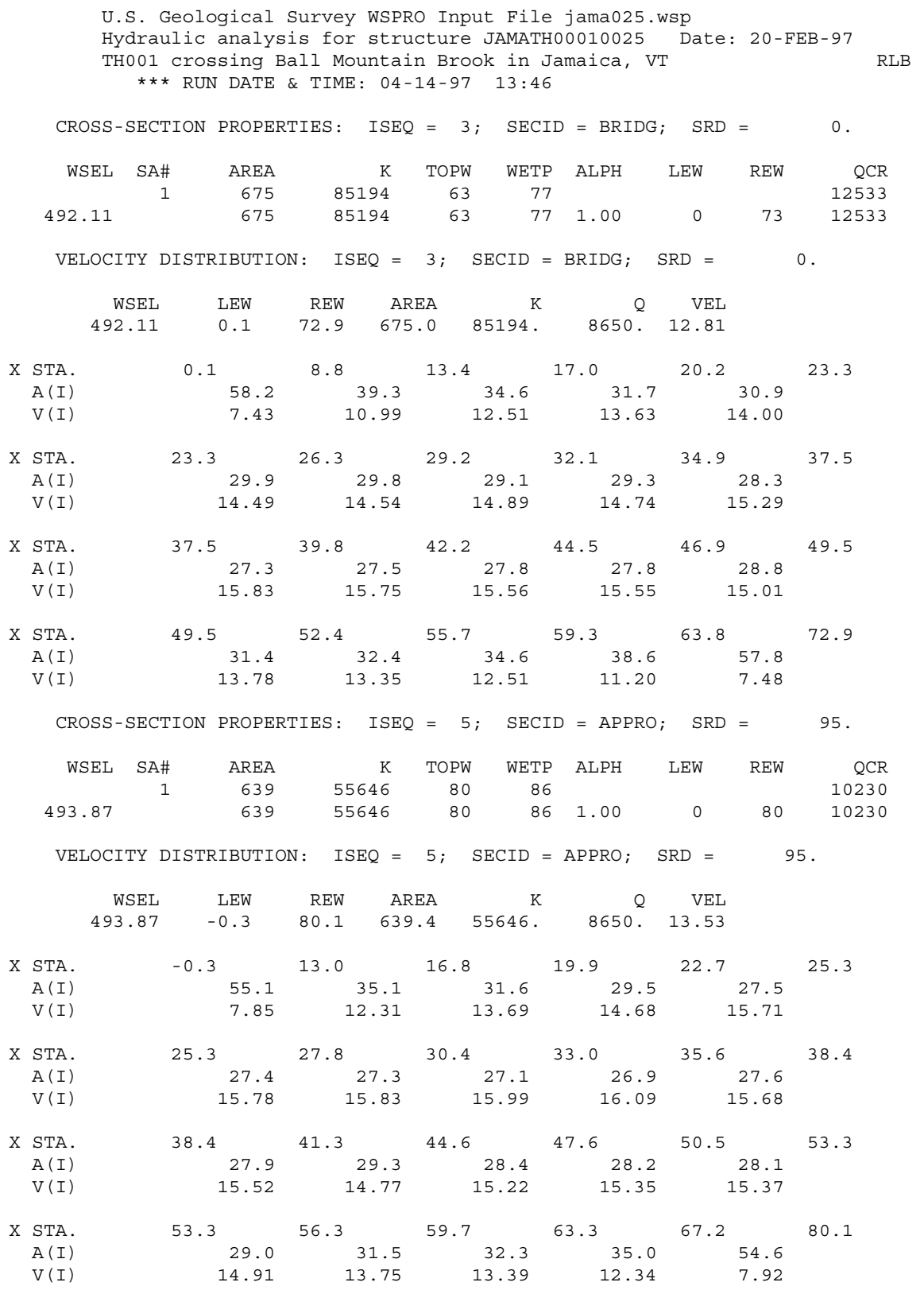


WSPRO OUTPUT FILE (continued)

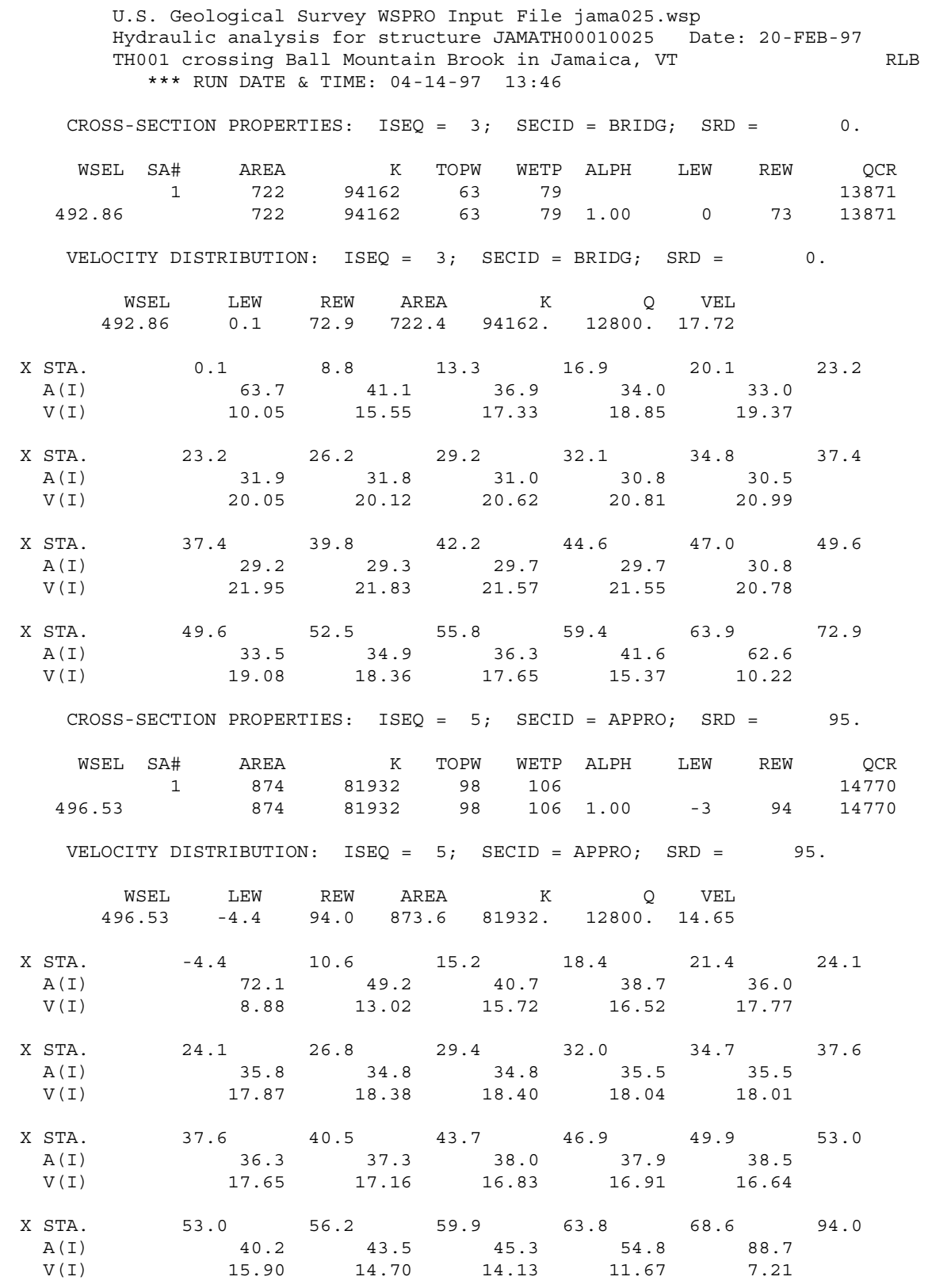


WSPRO OUTPUT FILE (continued)

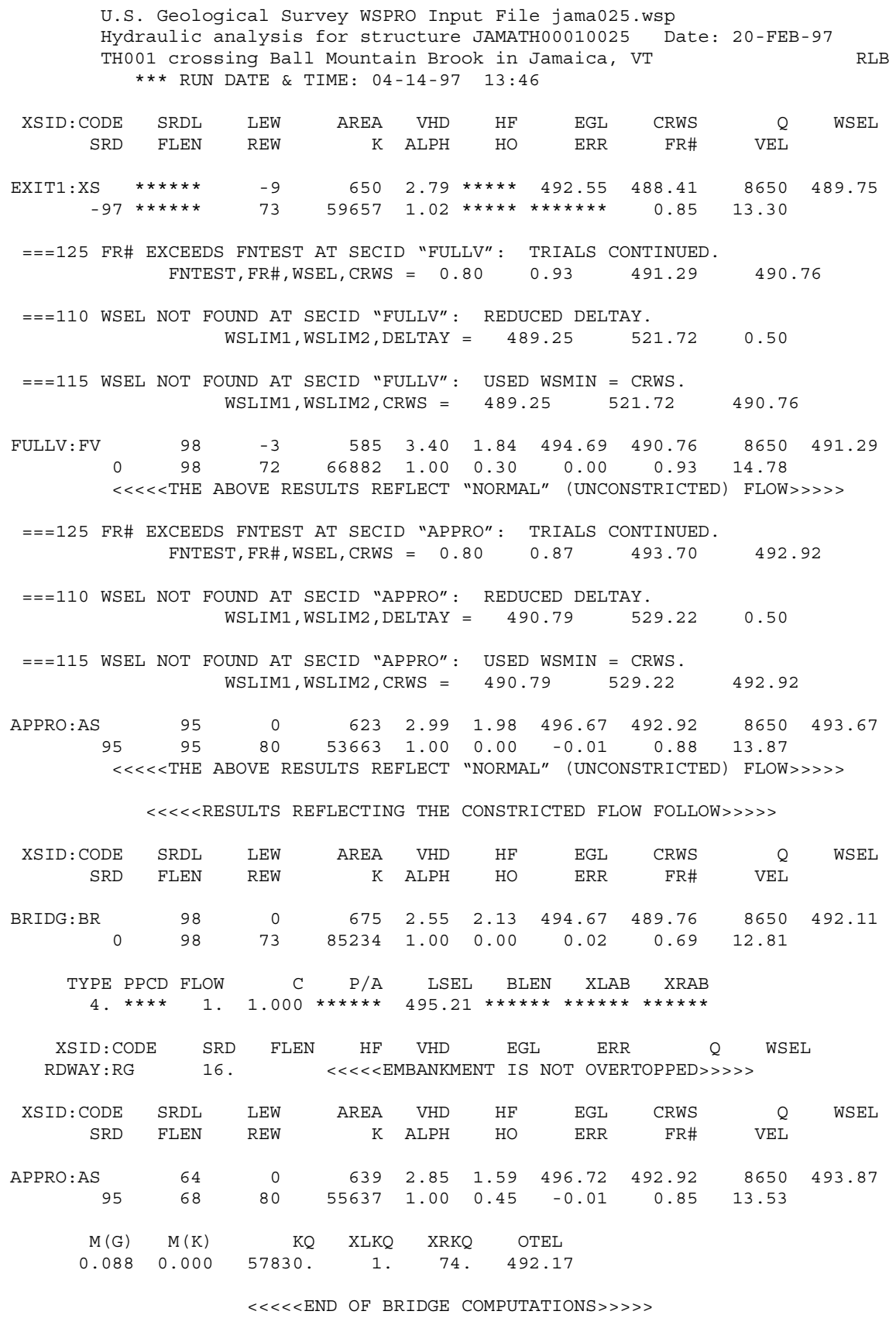

FIRST USER DEFINED TABLE.

\begin{tabular}{|c|c|c|c|c|c|c|c|c|}
\hline XSID : CODE & SRD & LEW & REW & $\mathrm{Q}$ & $\mathrm{K}$ & AREA & VEL & WSEI \\
\hline EXIT1:XS & -98 & -10 & 73. & 8650 . & 59657 . & 650. & 13.30 & 489.75 \\
\hline FULLV : FV & 0 . & -4 & 72 . & 8650 . & 66882. & 585 . & 14.78 & 491.29 \\
\hline BRIDG : BR & 0 . & 0 & 73. & 8650 . & 85234 & 675 & 12.81 & 492.11 \\
\hline RDWAY : RG & \multicolumn{3}{|c|}{$16 . * * * * * * * * * * * * * *$} & \multicolumn{3}{|c|}{$0 . * * * * * * * * * * * * * * * * * * *$} & \multicolumn{2}{|c|}{$1.00 * * * * * * * *$} \\
\hline APPRO : AS & 95. & 0 . & 80. & 8650. & 55637 . & 639. & 13.53 & 493.87 \\
\hline XSID : CODE & XLKQ & XRKQ & & & & & & \\
\hline APPRO : AS & 1. & 74. & $5^{\prime}$ & & & & & \\
\hline
\end{tabular}

SECOND USER DEFINED TABLE.

$\begin{array}{lcrrrrrrrr}\text { XSID }: \text { CODE } & \text { CRWS } & \text { FR\# } & \text { YMIN } & \text { YMAX } & \text { HF } & \text { HO } & \text { VHD } & \text { EGL } & \text { WSEL } \\ \text { EXIT1 :XS } & 488.41 & 0.85 & 477.06 & 519.37 * * * * * * * * * * & 2.79 & 492.55 & 489.75 \\ \text { FULLV }: \text { FV } & 490.76 & 0.93 & 479.41 & 521.72 & 1.84 & 0.30 & 3.40 & 494.69 & 491.29 \\ \text { BRIDG : BR } & 489.76 & 0.69 & 478.59 & 495.74 & 2.13 & 0.00 & 2.55 & 494.67 & 492.11 \\ \text { RDWAY : RG } & * * * * * * * * * * * * * * * * & 497.70 & 516.99 * * * * * * * * * * * * * * * * * * * * * * * * * * * * * * * \\ \text { APPRO: AS } & 492.92 & 0.85 & 483.16 & 529.22 & 1.59 & 0.45 & 2.85 & 496.72 & 493.87\end{array}$


WSPRO OUTPUT FILE (continued)

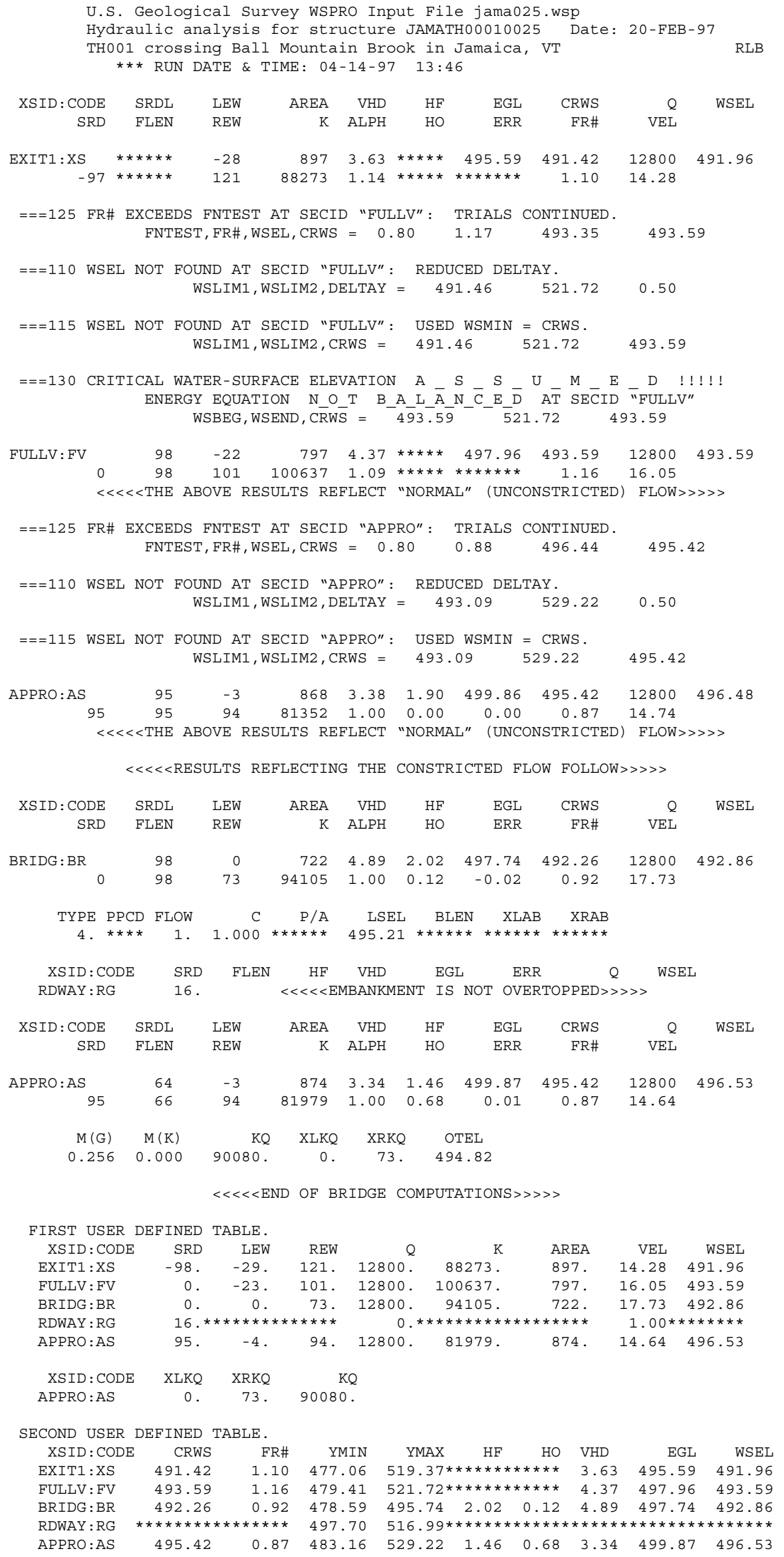




\section{APPENDIX C:}

\section{BED-MATERIAL PARTICLE-SIZE DISTRIBUTION}




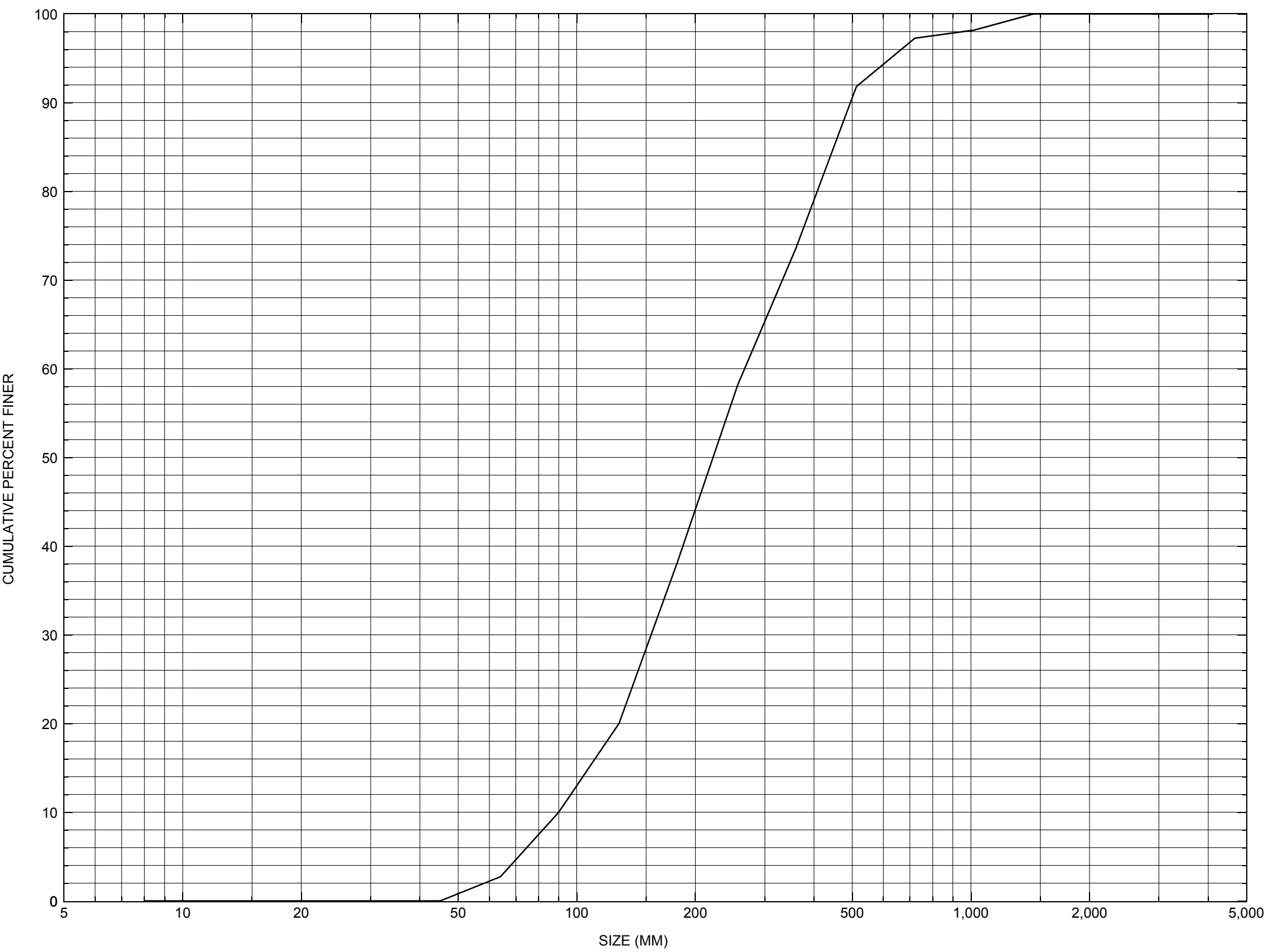

Appendix C. Bed material particle-size distribution for a pebble count in the channel approach of structure JAMATH00010025, in Jamaica, Vermont. 


\section{APPENDIX D: \\ HISTORICAL DATA FORM}




\section{Structure Number JAMATH00010025}

\section{General Location Descriptive}

Data collected by (First Initial, Full last name) $\mathbf{E}$. BOEHMLER

Date $(M M / D D / Y Y) \_\mathbf{0 3} / \underline{29} / \underline{95}$

Highway District Number (I - 2; nn) $\mathbf{0 2}$

Town (FIPS place code; I - 4; nnnnn) $\mathbf{3 6 1 7 5}$

Waterway (I - 6) BALL MOUNTAIN BROOK

Route Number TH001

Topographic Map Jamaica

Latitude (I - 16; nnnn.n) $\mathbf{4 3 0 5 4}$
County (FIPS county code; I - 3; nnn)

Mile marker (I - 11; nnn.nnn) $\mathbf{0 0 0 0 0 0}$

Road Name (I - 7): -

Vicinity (I - 9) 2.0 MI TO JCT W VT30

Hydrologic Unit Code: $\mathbf{0 1 0 8 0 1 0 7}$

Longitude (i - 17; nnnnn.n) $\mathbf{7 2 4 8 4}$

\section{Select Federal Inventory Codes}

FHWA Structure Number $(I$ - 8) 10130900251309

Maintenance responsibility $(I-21 ; n n) \quad \mathbf{0 3}$

Year built (I - 27; YYYY) 1978

Average daily traffic, ADT (I - 29; nnnnnn) 000140

Year of ADT (I - 30; YY) $\mathbf{9 1}$

Opening skew to Roadway $(I-34 ; n n) \quad 30$

Operational status $(I-41 ; X) \mathbf{A}$

Structure type (I - 43; nnn) $\mathbf{3 0 2}$

Approach span structure type $(I-44 ; n n n) \quad \mathbf{0 0 0}$

Number of spans (I - 45; nnn) $\mathbf{0 0 1}$

Number of approach spans (I - 46; nnnn) $\mathbf{0 0 0 0}$

Comments:

The structural inspection report of 9/13/93 indicates the structure is a single span steel stringer type bridge with a concrete deck and an asphalt roadway surface. The right abutment wall and the wingwalls are concrete. The left abutment wall is "laid-up" stone with a concrete cap and concrete facing at the upstream end on top of a massive bedrock outcrop. The right abutment reportedly has a few randomly distributed minor cracks. The footing is noted as "not in view" at the surface and there is boulder riprap placed in front of the wall. The left abutment is reported as "quite" stable. The waterway is noted as proceeding nearly straight through the structure. The streambed consists of stone (Continued, page 31) 


\section{Bridge Hydrologic Data}

Is there hydrologic data available? $\underline{\mathbf{Y}}$ if No, type ctrl- $n$ VTAOT Drainage area $\left(\mathrm{mi}^{2}\right): \underline{\mathbf{2 9 . 2}}$

Terrain character:

Stream character \& type: -

Streambed material:

Discharge Data (cfs):

$$
\mathrm{Q}_{2.33} \frac{-}{\mathbf{7 2 0 0}}
$$

$\mathrm{Q}_{10} \frac{\mathbf{4 1 2 5}}{\mathbf{8 6 5 0}}$

$\mathrm{Q}_{25} \mathbf{5 7 5 0}$

$Q_{500}$

Record flood date $(M M / D D / Y Y)$ :

Water surface elevation (ft): -

Estimated Discharge (cfs): Velocity at $\mathrm{Q} \underline{\mathbf{2 5}}$ $(\mathrm{ft} / \mathrm{s}): \mathbf{1 6 . 6}$

Ice conditions (Heavy, Moderate, Light) : Debris (Heavy, Moderate, Light):

The stage increases to maximum highwater elevation (Rapidly, Not rapidly):

The stream response is (Flashy, Not flashy):

Describe any significant site conditions upstream or downstream that may influence the stream's stage: -

Watershed storage area (in percent):

The watershed storage area is: - (1-mainly at the headwaters; 2- uniformly distributed; 3-immediatly upstream oi the site)

Water Surface Elevation Estimates for Existing Structure:

\begin{tabular}{|l|l|l|l|l|l|}
\hline Peak discharge frequency & $Q_{2.33}$ & $Q_{10}$ & $Q_{25}$ & $Q_{50}$ & $Q_{100}$ \\
Water surface elevation (ft)) & - & $\mathbf{6 . 1}$ & $\mathbf{7 . 5}$ & $\mathbf{8 . 6}$ & $\mathbf{9 . 6}$ \\
Velocity $(\mathrm{ft} / \mathrm{sec})$ & - & - & $\mathbf{1 6 . 6}$ & - & - \\
\hline
\end{tabular}

Long term stream bed changes: -

Is the roadway overtopped below the $\mathrm{Q}_{100}$ ? (Yes, No, Unknown): $\mathbf{U}$ Frequency: Relief Elevation $(f t)$ : Discharge over roadway at $Q_{100}\left(f t^{3} / \mathrm{sec}\right)$ :

Are there other structures nearby? (Yes, No, Unknown): $\mathbf{U}$ Upstream distance (miles): Town: If No or Unknown, type ctrl-n os Highway No. : Structure No. : Year Built:

Clear span (ft): Clear Height (ft): Full Waterway $\left(f t^{2}\right)$ : 
Downstream distance (miles): Town: Year Built:

Highway No. : Structure No. : Structure Type:

Clear span (ft): Clear Height $(f t)$ :

Full Waterway $\left(f^{2}\right)$ :

Comments:

and boulders on the right half under the bridge and is bedrock on the left half. A full hydraulic report was not generated. The hydraulic report recommended using class IV type stone fill.

\section{USGS Watershed Data}

Watershed Hydrographic Data

Drainage area $(D A) \stackrel{29.48}{\mathrm{mi}^{2}}$ Lake and pond area $\mathbf{0 . 0 3}$ $\mathrm{mi}^{2}$

Watershed storage (ST)

Bridge site elevation 970 0.1 Main channel length 10.33 $\mathrm{ft}$ $\%$ $10 \%$ channel length elevation $\mathbf{1 2 0 1}$ $\mathrm{ft} \quad 85 \%$ channel length elevation 2067 $\mathrm{ft}$

Main channel slope (S) 111.83 $\mathrm{ft} / \mathrm{mi}$

Watershed Precipitation Data

Average site precipitation in Average headwater precipitation in

Maximum 2yr-24hr precipitation event $(124,2)$ in

Average seasonal snowfall (Sn) $\mathrm{ft}$ 


\section{Bridge Plan Data}

Are plans available? $\underline{Y}$ If no, type ctrl-n $p / \quad$ Date issued for construction (MM/YYYY): $\underline{\mathbf{0 2}} / \mathbf{1 9 7 7}$ Project Number DSR0032 \& TH2801 (1977)

Minimum channel bed elevation: $\underline{479.5}$

Low superstructure elevation: USLAB $\underline{\mathbf{4 8 9 . 8 6}}$ DSLAB $\underline{\mathbf{4 8 9 . 6 2}}$ USRAB $\underline{\mathbf{4 9 0 . 7 5}}$ DSRAB $\underline{\mathbf{4 9 0 . 6 5}}$

Benchmark location description:

BM\#1: spike in root of a 36 inch maple, elevation 500.0; 350 feet right bankward from the right abutment on the downstream side of the road about 40 feet from the roadway. BM\#2: spike in root of 24 inch maple, assumed elevation 492.27; 60 feet from left abutment downstream side of road about 15 feet from the roadway.

Reference Point (MSL, Arbitrary, Other): Arbitrary $\quad$ Datum (NAD27, NAD83, Other): Arbitrary Foundation Type: 1

If 1: Footing Thickness $\mathbf{2 . 0} \quad$ Footing bottom elevation: $\underline{474 . *}$

If 2: Pile Type:___ (1-Wood; 2-Steel or metal; 3-Concrete) Approximate pile driven length:

If 3: Footing bottom elevation:

Is boring information available? $\mathbf{N}$ If no, type ctrl- $n$ bi Number of borings taken: _-

Foundation Material Type: $\mathbf{3}$ (1-regolith, 2-bedrock, 3-unknown)

Briefly describe material at foundation bottom elevation or around piles:

NO FOUNDATION MATERIAL INFORMATION

Comments:

*Footing bottom elevations are left: 474.0 and right: 475.0 . Downstream left wingwall has a cut away section at the end 7 feet below top most point (492.5) down to 485.5 then declining under the wall to 482.0 to the footing base at $\mathbf{4 7 4 . 0}$. 


\section{Cross-sectional Data}

Is cross-sectional data available? $\underline{\mathbf{Y}}$ If no, type ctrl-n xs

Source (FEMA, VTAOT, Other)? FEMA

Comments: Several channel cross sections are also available from VT AOT.

\begin{tabular}{|l|l|l|l|l|l|l|l|l|l|l|l|}
\hline Station & $\mathbf{1 5 9}$ & $\mathbf{1 8 9}$ & $\mathbf{2 2 6}$ & $\mathbf{2 3 1}$ & - & - & - & - & - & - & - \\
\hline Feature & LAB & - & - & RAB & - & - & - & - & - & - & - \\
\hline $\begin{array}{l}\text { Low cord } \\
\text { elevation }\end{array}$ & $\mathbf{9 6 5 . 3}$ & $\mathbf{9 6 5 . 8}$ & $\mathbf{9 6 6 . 5}$ & $\mathbf{9 6 6 . 6}$ & - & - & - & - & - & - & - \\
\hline $\begin{array}{l}\text { Bed } \\
\text { elevation }\end{array}$ & $\mathbf{9 5 6 . 5}$ & $\mathbf{9 5 5 . 8}$ & $\mathbf{9 5 6 . 8}$ & $\mathbf{9 5 9 . 7}$ & - & - & - & - & - & - & - \\
\hline $\begin{array}{l}\text { Low cord to } \\
\text { bed length }\end{array}$ & $\mathbf{8 . 8}$ & $\mathbf{1 0 . 0}$ & $\mathbf{9 . 7}$ & $\mathbf{6 . 9}$ & - & - & - & - & - & - & - \\
\hline Station & - & - & - & - & - & - & - & - & - & - & - \\
\hline Feature & - & - & - & - & - & - & - & - & - & - & - \\
\hline $\begin{array}{l}\text { Low cord } \\
\text { elevation }\end{array}$ & - & - & - & - & - & - & - & - & - & - & - \\
\hline $\begin{array}{l}\text { Bed } \\
\text { elevation }\end{array}$ & - & - & - & - & - & - & - & - & - & - & - \\
\hline $\begin{array}{l}\text { Low cord to } \\
\text { bed length }\end{array}$ & - & - & - & - & - & - & - & - & - & - & - \\
\hline
\end{tabular}

Source (FEMA, VTAOT, Other)?

Comments: -

\begin{tabular}{|l|l|l|l|l|l|l|l|l|l|l|l|}
\hline Station & - & - & - & - & & - & - & - & - & - & - \\
\hline Feature & - & - & - & - & - & - & - & - & - & - & - \\
\hline $\begin{array}{l}\text { Low cord } \\
\text { elevation }\end{array}$ & - & - & - & - & - & - & - & - & - & - & - \\
\hline $\begin{array}{l}\text { Bed } \\
\text { elevation }\end{array}$ & - & - & - & - & - & - & - & - & - & - & - \\
\hline $\begin{array}{l}\text { Low cord to } \\
\text { bed length }\end{array}$ & - & - & - & - & - & - & - & - & - & - & - \\
\hline Station & - & - & - & - & - & - & - & - & - & - & - \\
\hline Feature & - & - & - & - & - & - & - & - & - & - & - \\
\hline $\begin{array}{l}\text { Low cord } \\
\text { elevation }\end{array}$ & - & - & - & - & - & - & - & - & - & - & - \\
\hline $\begin{array}{l}\text { Bed } \\
\text { elevation }\end{array}$ & - & - & - & - & - & - & - & - & - & - & - \\
\hline $\begin{array}{l}\text { Low cord to } \\
\text { bed length }\end{array}$ & - & - & - & - & - & - & - & - & - & - & - \\
\hline
\end{tabular}




\section{APPENDIX E: \\ LEVEL I DATA FORM}


U. S. Geological Survey

Bridge Field Data Collection and Processing Form

Qa/Qc Check by: EW Date: $\underline{\mathbf{1 0 / 2 2 / 9 6}}$

\section{Structure Number JAMATH00010025} Computerized by: $\underline{\mathbf{E W} \text { Date: } 10 / 24 / 96}$

Reviewd by: $\quad$ RB Date: $\underline{\mathbf{0 5} / 07 / 97}$

\section{A. General Location Descriptive}

1. Data collected by (First Initial, Full last name) R. BURNS

2. Highway District Number $\mathbf{0 2}$

Date $(M M / D D / Y Y) \mathbf{0 8} / \underline{13} / \underline{1996}$

County WINDHAM (025)

Waterway ( $($ - 6) BALL MOUNTAIN BROOK

Route Number TH001

3. Descriptive comments:

Located 2.0 miles to junction with Vermont 30. This is a steel stringer type bridge with a concrete deck.

Bridge plaque states bridge number DSR0032 and TH 2801, 1977.

\section{B. Bridge Deck Observations}
4. Surface cover... LBUS 6
RBUS 6
LBDS 6
RBDS 4
Overall 6

(2b us, ds,lb,rb: 1- Urban; 2- Suburban; 3- Row crops; 4- Pasture; 5- Shrub- and brushland; 6- Forest; 7- Wetland)
5. Ambient water surface... US 2
UB 2
DS 2
(1- pool; 2- riffle)

6. Bridge structure type 1 (1- single span; 2- multiple span; 3- single arch; 4- multiple arch; 5-cylindrical culvert; 6- box culvert; or 7- other)
7. Bridge length $\mathbf{7 8}$
(feet)
Span length $\mathbf{7 5}$
(feet)
Bridge width 24.7 (feet)

\section{Road approach to bridge:}
8. LB 1
RB 2
( 0 even, 1- lower, 2- higher)
9. LB
RB 1
(1-Paved, 2- Not paved)

10. Embankment slope (run / rise in feet / foot)

$$
\text { US left }
$$

2.1:1

US right

2.5:1

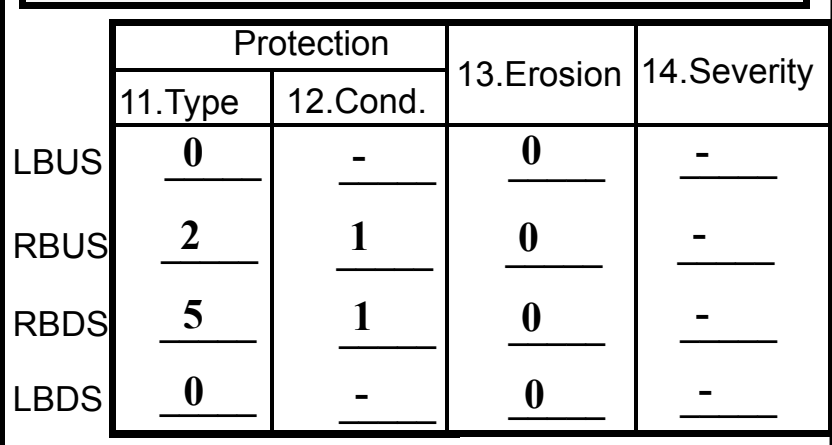

Bank protection types: 0- none; 1- $<12$ inches;

2- < 36 inches; 3- < 48 inches;

4- < 60 inches; 5- wall / artificial levee

Bank protection conditions: 1- good; 2- slumped;

3- eroded; 4- failed

Erosion: 0 - none; 1- channel erosion; 2 -

road wash; 3- both; 4- other

Erosion Severity: 0 - none; 1- slight; 2- moderate; 3- severe

\section{Channel approach to bridge (BF):}

15. Angle of approach: 5

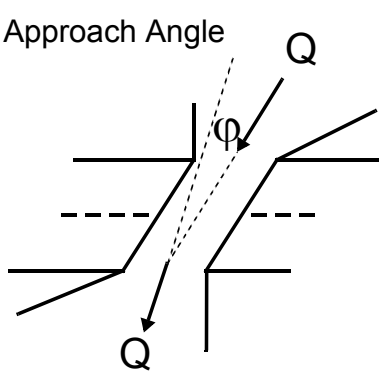

17. Channel impact zone 1 :

Where? LB $(L B, R B)$

Range? 300 feet $\underline{\mathbf{U S}}$

Channel impact zone 2:

Where? _ _ $(L B, R B)$

Range? - $\quad$ feet -

(US, UB, DS) to = feet Impact Severity: 0- none to very slight; 1- Slight; 2- Moderate; 3- Severe

16. Bridge skew: 30 Bridge Skew Angle

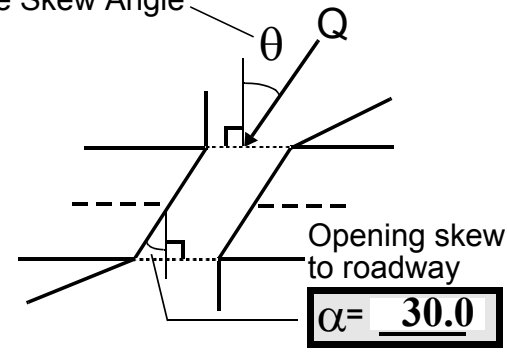

\section{Exist? $\mathbf{Y}(Y$ or $N)$}

Severity 1

(US, UB, DS) to $\underline{\mathbf{2 5 0}}$ feet $\underline{\mathbf{U S}}$

Exist? $\mathbf{N} \quad($ Yor $N)$

Severity - 
18. Bridge Type: 4

1a- Vertical abutments with wingwalls

$1 \mathrm{~b}$ - Vertical abutments without wingwalls

2- Vertical abutments and wingwalls, sloping embankment Wingwalls perpendicular to abut. face

3- Spill through abutments

4- Sloping embankment, vertical wingwalls and abutments

Wingwall angle less than $90^{\circ}$.

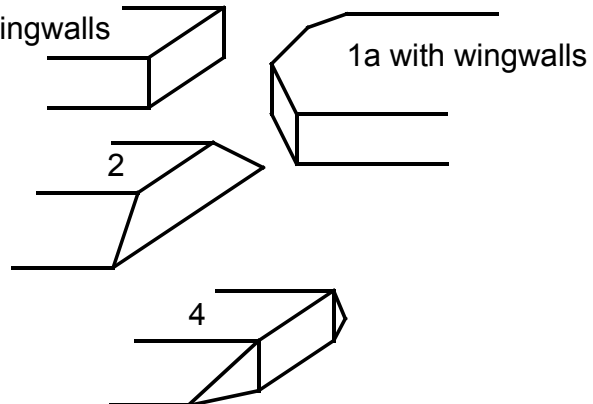

19. Bridge Deck Comments (surface cover variations, measured bridge and span lengths, bridge type variations, approach overflow width, etc.)

\#4: On the right bank downstream, there is a house with a large lawn and gravel driveway, forest is beyond.

\#7: Measured values during site visit: bridge length $=\mathbf{7 7 . 5}$ feet; span length $=73$ feet; and bridge width $=\mathbf{2 6}$ feet between inside of curb edges, the curb is 1 foot wide.

\#11: On the right bank downstream, there is a small stone wall along the road embankment. It is acting like a retaining wall for the flower garden which exists along the road.

\section{Upstream Channel Assessment}

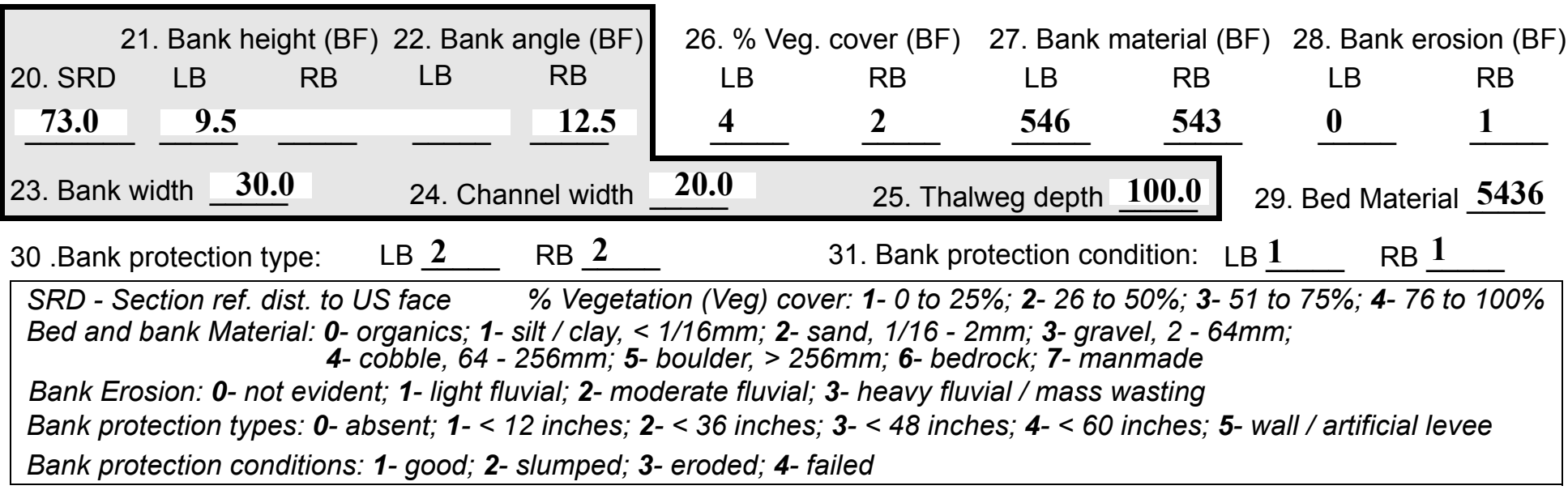

32. Comments (bank material variation, minor inflows, protection extent, etc.):

\#27: There is a bedrock outcrop on the left bank that protrudes into the stream from 300 feet upstream to 150 feet upstream.

\#30: The left bank protection extends from 80 feet upstream to 0 feet upstream. The old laid-up stone abutment wall is on the left bank from 45 feet upstream to 30 feet upstream.

The right bank protection extends from 80 feet upstream to the upstream end of the wingwall. 

feet US

(US, UB) to 25 feet $\underline{\text { DS }}$ (US, UB, DS) positioned $\mathbf{0}$ $\%$ LB to 40 $\% R B$

37. Material: $\mathbf{3 2 4 5}$

38. Point or side bar comments (Circle Point or Side; Note additional bars, material variation, status, etc.):

Side bar goes under the bridge along the bottom of the left abutment protection. Mid-bar distance is at the upstream bridge face.

Another point bar exists from 220 feet upstream to 165 feet upstream on the right bank. It is composed of cobbles, boulders and gravel. At 185 feet upstream it is 20 feet wide.

39. Is a cut-bank present? $\mathbf{N}$ ( $Y$ or if $N$ type ctrl-n $c b)$

40. Where? (LB or $R B)$

41. Mid-bank distance: 42. Cut bank extent: feet (US, UB) to feet (US, UB, DS)

43. Bank damage: (1- eroded and/or creep; 2- slip failure; 3- block failure)

44. Cut bank comments (eg. additional cut banks, protection condition, etc.):

NO CUT BANKS

\section{Is channel scour present? $\mathbf{Y}$ ( $Y$ or if $N$ type ctrl-n cs)}

47. Scour dimensions: Length $\mathbf{1 5}$

Width 10 Depth : 1

46. Mid-scour distance: $\mathbf{0}$

48. Scour comments (eg. additional scour areas, local scouring process, etc.):

This scour hole extends from $10 \mathrm{ft}$. upstream to $5 \mathrm{ft}$. under the bridge, measured from the upstream bridge face. An additional scour hole is along the bedrock outcrop on the left bank upstream. It is $30 \mathrm{ft}$. long, $5 \mathrm{ft}$. wide and $1.5 \mathrm{ft}$. deep. The mid-scour distance is at $200 \mathrm{ft}$. upstream and it is positioned from $40 \%$ left bank to $60 \%$ right bank.

\section{Are there major confluences? $\mathbf{N}$}

51. Confluence 1: Distance -

Confluence 2: Distance -

52. Enters on -

Enters on -

54. Confluence comments (eg. confluence name):

NO MAJOR CONFLUENCES
50. How many? -

53. Type(1-perennial; 2- ephemeral) Type (1-perennial; 2-ephemeral) ( $(L B$ or $R B)$ (LB or $R B)$ (1-perennial; 2- ephemera)

55. Channel restraint (BF)? LB 2

\section{Under Bridge Channel Assessment}

\begin{tabular}{|c|c|c|c|c|c|c|c|}
\hline 56. Heig & t (BF) & 57 Angle & (BF) & & (BF) & & (BF) \\
\hline LB & RB & LB & $\mathrm{RB}$ & LB & RB & LB & RB \\
\hline 51.0 & & 1.5 & & 2 & 7 & 7 & - \\
\hline
\end{tabular}

63. Bed Material -

Bed and bank Material: 0- organics; 1- silt / clay, < 1/16mm; 2- sand, 1/16 - 2mm; 3- gravel, 2 - 64mm; 4- cobble, 64 - 256mm; 5- boulder, > 256mm; 6- bedrock; 7- manmade

Bank Erosion: 0- not evident; 1- light fluvial; 2- moderate fluvial; 3- heavy fluvial / mass wasting

64. Comments (bank material variation, minor inflows, protection extent, etc.):

5 
65. Debris and Ice Is there debris accumulation?

$(Y$ or $N)$ 66. Where? $\underline{Y}$

(1- Upstream; 2- At bridge; 3- Both)

67. Debris Potential 2 (1-Low; 2-Moderate; 3- High)

68. Capture Efficiency 2

(1-Low; 2- Moderate; 3- High)

69. Is there evidence of ice build-up? 1 (Y or $N)$

Ice Blockage Potential $\underline{\mathbf{N}}$

(1- Low; 2- Moderate; 3- High)

70. Debris and Ice Comments:

1

There is debris caught in the stone fill protection at the upstream and downstream faces of the bridge on the left bank.

\begin{tabular}{|l|c|c|c|c|c|c|c|c|}
\hline Abutments & $\begin{array}{c}\text { 71. Attack } \\
\angle \text { (BF) }\end{array}$ & $\begin{array}{c}72 \text {. Slope } \angle \\
\text { (Qmax) }\end{array}$ & $\begin{array}{c}\text { 73. Toe } \\
\text { loc. (BF) }\end{array}$ & $\begin{array}{c}\text { 74. Scour } \\
\text { Condition }\end{array}$ & $\begin{array}{c}75 . \text { Scour } \\
\text { depth }\end{array}$ & $\begin{array}{c}\text { 76. Exposure } \\
\text { depth }\end{array}$ & 77. Material & 78. Length \\
\hline LABUT & & $\mathbf{5}$ & $\mathbf{9 0}$ & $\mathbf{2}$ & $\mathbf{0}$ & - & - & $\mathbf{9 0 . 0}$ \\
\hline RABUT & $\mathbf{1}$ & - & $\mathbf{9 0}$ & & & $\mathbf{2}$ & $\mathbf{0}$ & $\mathbf{6 3 . 0}$ \\
\hline
\end{tabular}

Pushed: $L B$ or RB

Toe Location (Loc.): 0- even, 1- set back, 2- protrudes

Scour cond.: 0- not evident; 1- evident (comment); 2- footing exposed; 3-undermined footing; 4- piling exposed; 5- settled; 6- failed

Materials: 1- Concrete; 2- Stone masonry or drywall; 3- steel or metal; 4- wood

79. Abutment comments (eg. undermined penetration, unusual scour processes, debris, etc.):

80. Wingwalls:

Exist? Material? Scour Scour Exposure $\begin{aligned} & 81 . \\ & \text { Angle? Length? }\end{aligned}$ Condition? depth? depth?

USLWW:

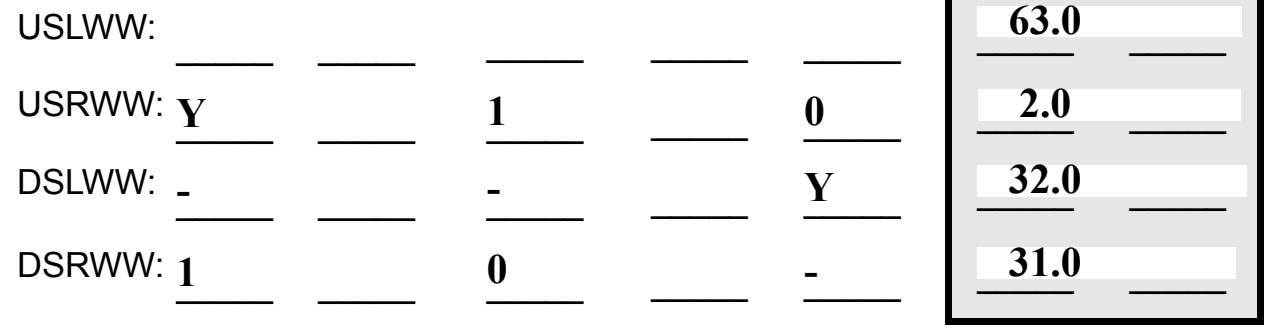

Wingwall materials: 1- Concrete; 2- Stone masonry or drywall; 3- steel or metal; 4- wood

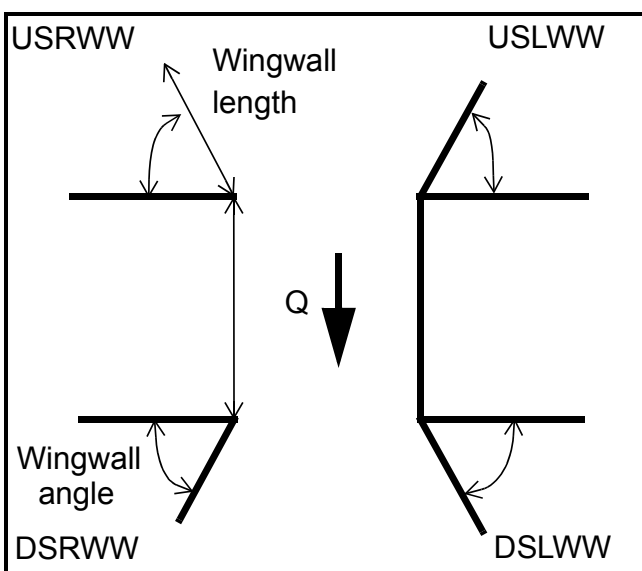

82. Bank / Bridge Protection:

\begin{tabular}{|l|l|l|l|l|l|l|l|c|}
\hline Location & USLWW & USRWW & LABUT & RABUT & LB & RB & DSLWW & DSRWW \\
\hline Type & - & $\mathbf{0}$ & $\mathbf{Y}$ & - & $\mathbf{1}$ & $\mathbf{1}$ & $\mathbf{1}$ & $\mathbf{1}$ \\
\hline Condition & $\mathbf{Y}$ & - & $\mathbf{1}$ & - & $\mathbf{1}$ & $\mathbf{1}$ & $\mathbf{1}$ & $\mathbf{1}$ \\
\hline Extent & $\mathbf{1}$ & - & $\mathbf{0}$ & $\mathbf{2}$ & $\mathbf{2}$ & $\mathbf{2}$ & $\mathbf{2}$ & - \\
\hline
\end{tabular}

Bank / Bridge protection types: 0- absent; 1- < 12 inches; 2- < 36 inches; 3- < 48 inches; 4- < 60 inches; 
83. Wingwall and protection comments (eg. undermined penetration, unusual scour processes, etc.):

-
-
-
-
-
2
1
1
2
1
1

\section{Piers:}

84. Are there piers? _ _ (Y or if $N$ type ctrl-n pr)

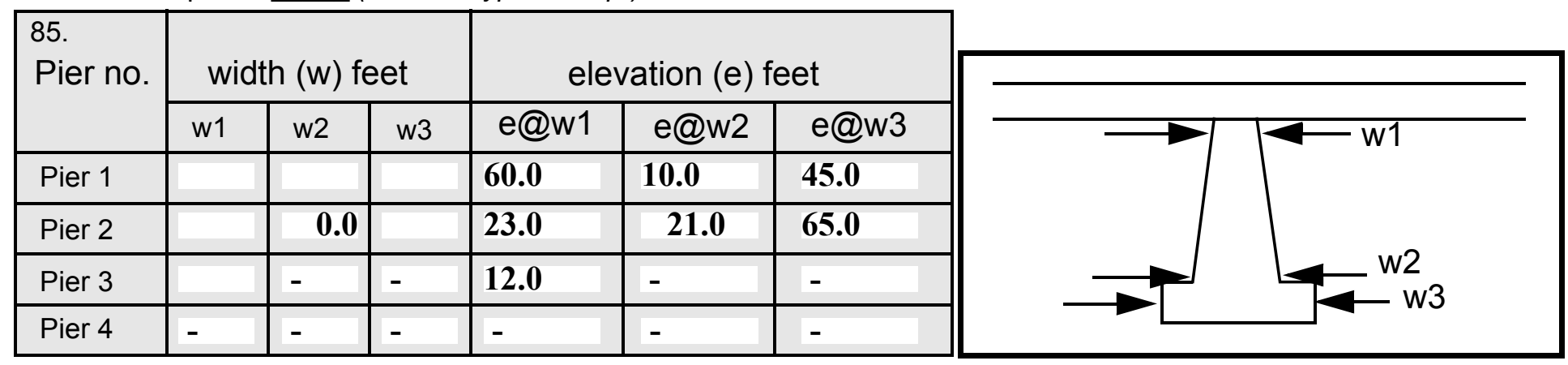

\begin{tabular}{|c|c|c|c|c|}
\hline Level 1 Pier Descr. & 1 & 2 & 3 & 4 \\
\hline 86. Location (BF) & & - & - & - \\
\hline 87. Type & & - & - & - \\
\hline 88. Material & & - & - & - \\
\hline 89. Shape & & - & - & - \\
\hline 90. Inclined? & & - & - & - \\
\hline 91. Attack $\angle(\mathrm{BF})$ & & - & - & - \\
\hline 92. Pushed & & - & - & - \\
\hline 93. Length (feet) & - & - & - & - \\
\hline 94. \# of piles & & - & - & - \\
\hline 95. Cross-members & & - & - & - \\
\hline 96. Scour Condition & & - & - & - \\
\hline 97. Scour depth & $\mathbf{N}$ & - & - & - \\
\hline 98. Exposure depth & - & - & - & - \\
\hline
\end{tabular}

LFP, LTB, LB, MCL, MCM, MCR, RB, RTB, RFP

1- Solid pier, 2- column, 3- bent

1-Wood; 2- concrete; 3- metal; 4- stone

1- Round; 2- Square; 3- Pointed

Y-yes; $N-$ no

$L B$ or $R B$

0- none; 1- laterals; 2- diagonals; 3- both

0- not evident; 1- evident (comment);

2- footing exposed; 3- piling exposed;

4- undermined footing; 5- settled; 6- failed 
99. Pier comments (eg. undermined penetration, protection and protection extent, unusual scour processes, etc.):

-
-
-
-
-
-
-
-
-

100.

\section{E. Downstream Channel Assessment}

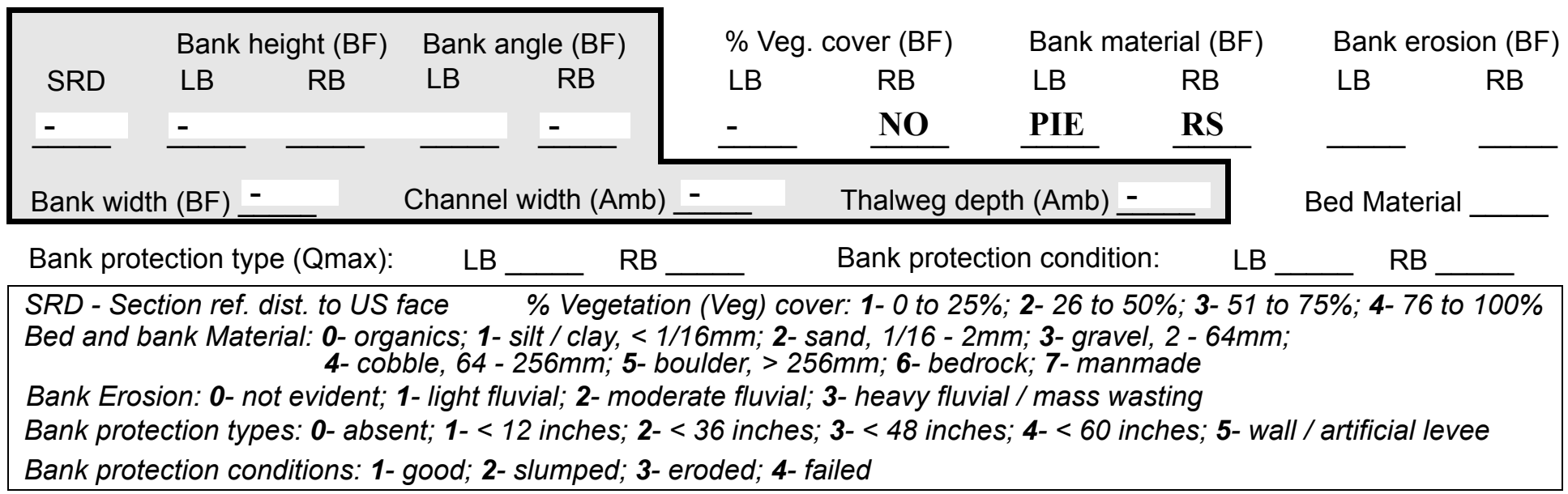

Comments (eg. bank material variation, minor inflows, protection extent, etc.):

$\mathbf{4}$
$\mathbf{5}$
$\mathbf{5 4 3}$
$\mathbf{1}$
$\mathbf{0}$
$\mathbf{5}$
$\mathbf{3}$
$\mathbf{3}$
$\mathbf{1}$
1

Right bank protection extends from 0 feet downstream to 200 feet downstream. At 70 feet downstream, the right bank protection changes from type 3 stone fill to type 2 native stone fill.

101. Is a drop structure present? ___ ( or $N$, if $N$ type ctrl-n ds) 102. Distance: ___ feet
103. Drop: - feet
104. Structure material: Lef (1- steel sheet pile; 2- wood pile; 3-concrete; 4- other)

105. Drop structure comments (eg. downstream scour depth):

$t$ bank protection extends from 0 feet downstream to 70 feet downstream. 
Point bar extent: feet

(US, UB, DS) to feet $\underline{\mathbf{N}}$ (US, UB, DS) positioned \%LB to NO \%RB

Material: DR

Point or side bar comments (Circle Point or Side; note additional bars, material variation, status, etc.):

\section{OP STRUCTURE}

Is a cut-bank present? (Y or if $N$ type ctrl- $n$ cb) Where? (LB or $R B)$

Mid-bank distance: $\underline{\mathbf{Y}}$

Cut bank extent: $\underline{0}$ DS feet 7 (US, UB, DS) to $\underline{\mathbf{1 5}}$ feet $\underline{\mathbf{U B}}$ (US, UB, DS)

Bank damage: 10 (1- eroded and/or creep; 2- slip failure; 3- block failure)

Cut bank comments (eg. additional cut banks, protection condition, etc.):

DS

90

100

342

Is channel scour present? Sid (Y or if $N$ type ctrl-n cs) Mid-scour distance: $\underline{\text { e bar }}$

Scour dimensions: Length is Width alon Depth: $\mathbf{g} \quad$ Positioned the \%

Scour comments (eg. additional scour areas, local scouring process, etc.):

ht abutment.

Are there major confluences? $\mathbf{Y}$ ( $Y$ or if $N$ type ctrl-n $m c)$

How many? $\underline{\mathbf{L B}}$

Confluence 1: Distance 190

Enters on $\underline{\mathbf{1 7 0}}$ ( $L B$ or $R B)$

Type $\underline{\mathbf{D S}}$

(1- perennial; 2- ephemeral)

Confluence 2: Distance 200

Enters on DS ( $L B$ or RB)

Type 1 (1- perennial; 2- ephemeral)

Confluence comments (eg. confluence name):

Bank is eroded on top of natural protection and some tree roots are exposed.

\section{F. Geomorphic Channel Assessment}

107. Stage of reach evolution

1- Constructed

2- Stable

3- Aggraded

4- Degraded

5- Laterally unstable

6- Vertically and laterally unstable 
108. Evolution comments (Channel evolution not considering bridge effects; See HEC-20, Figure 1 for geomorphic descriptors):

$\mathbf{Y}$

80

20

15

1.5

10

60

This scour hole exists downstream of large boulders across the channel at 70 feet downstream. The scour depth is based on a thalweg of 2.5 feet.

$\mathbf{N}$ 


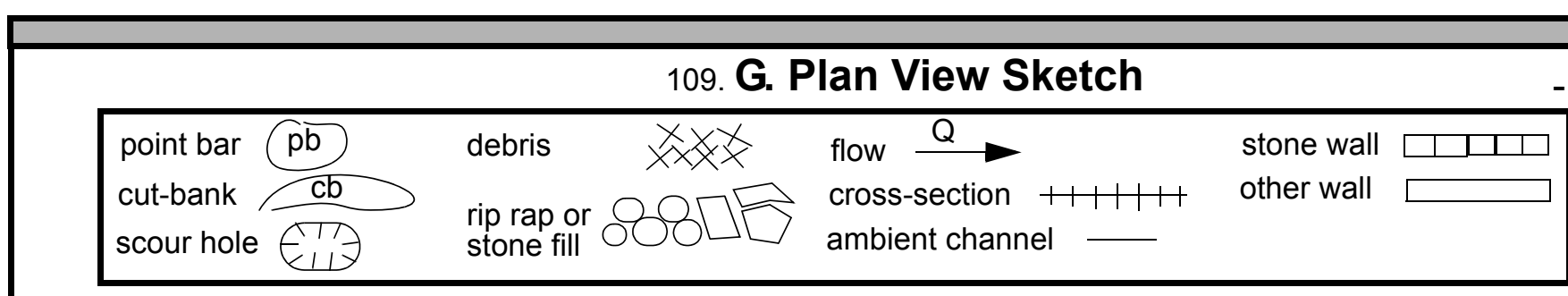


APPENDIX F:

SCOUR COMPUTATIONS 


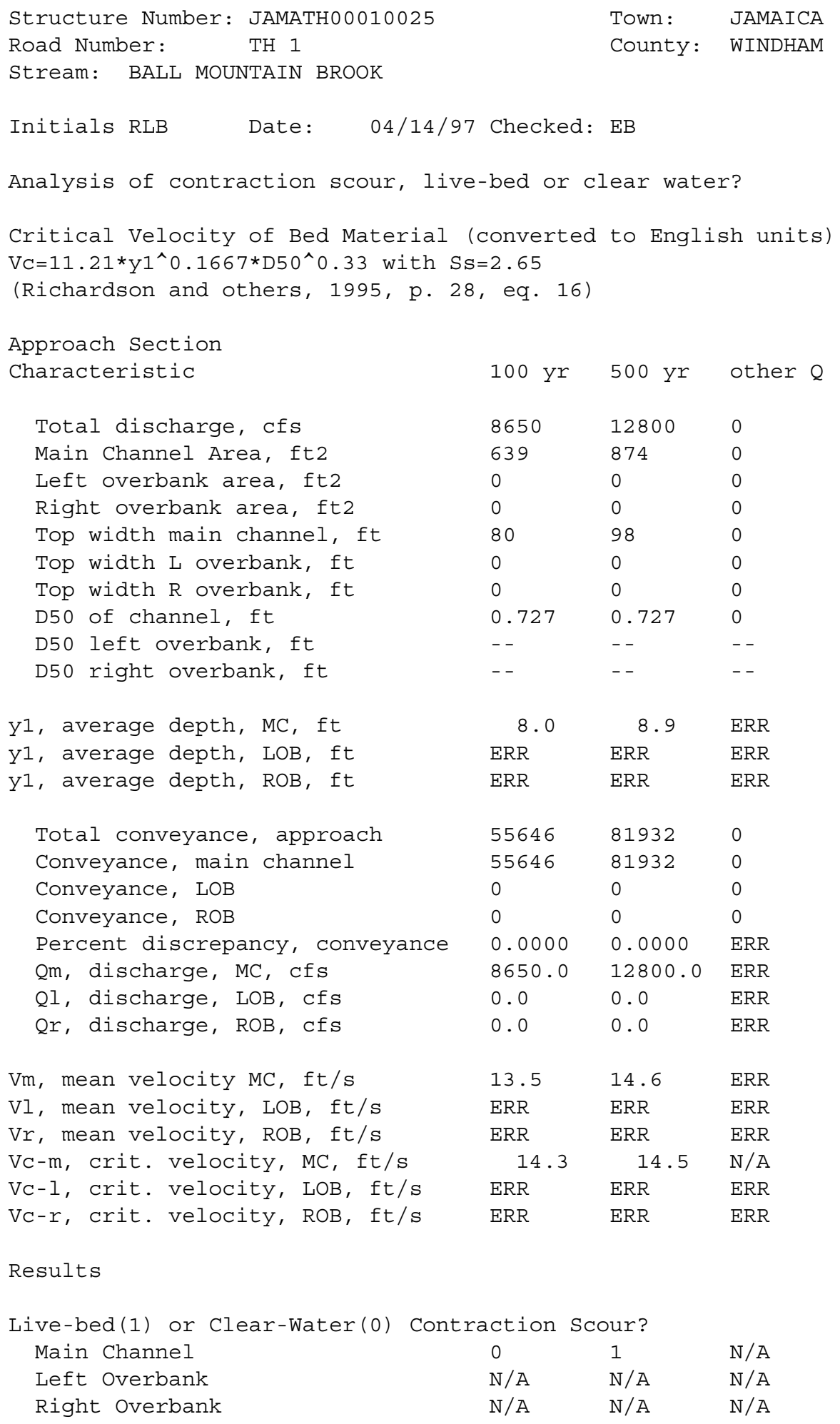


Live-Bed Contraction Scour

Laursen's Live Bed Contraction Scour

$\mathrm{Y} 2 / \mathrm{Y} 1=(\mathrm{Q} 2 / \mathrm{Q} 1)^{\wedge}(6 / 7) *(\mathrm{~W} 1 / \mathrm{W} 2)^{\wedge}(\mathrm{k} 1)$

ys $=$ y $2-y \_b r i d g e$

(Richardson and others, 1995, p. 30, eq. 17 and 18)

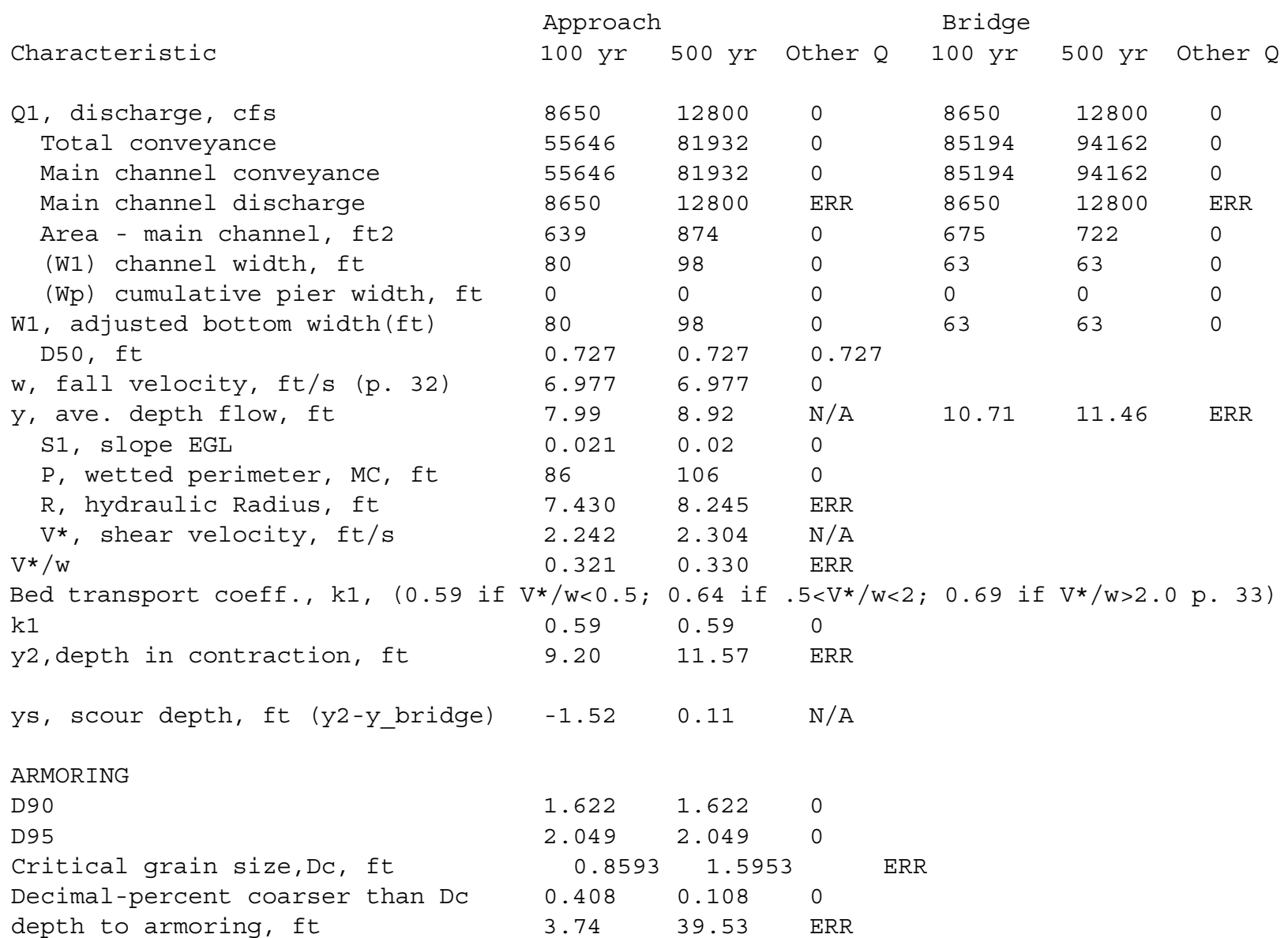

Clear water Contraction Scour in MAIN CHANNEL

$\mathrm{Y} 2=\left(\mathrm{Q} 2^{\wedge} 2 /\left(131 * \mathrm{Dm}^{\wedge}(2 / 3) * \mathrm{~W} 2^{\wedge} 2\right)\right)^{\wedge}(3 / 7) \quad$ Converted to English Units

ys $=$ y2-y_bridge

(Richardson and others, 1995, p. 32, eq. 20, 20a)

Approach Section

Main channel Area, ft2

Main channel width, ft

yl, main channel depth, ft

$\begin{array}{lll}\text { Q100 } & \text { Q500 } & \text { Qother } \\ 639 & 874 & 0 \\ 80 & 98 & 0 \\ 7.99 & 8.92 & \text { ERR }\end{array}$




\begin{tabular}{|c|c|c|c|}
\hline (Q) total discharge, cfs & 8650 & 12800 & 0 \\
\hline (Q) discharge thru bridge, cfs & 8650 & 12800 & 0 \\
\hline Main channel conveyance & 85194 & 94162 & 0 \\
\hline Total conveyance & 85194 & 94162 & 0 \\
\hline Q2, bridge MC discharge, cfs & 8650 & 12800 & ERR \\
\hline Main channel area, ft2 & 675 & 722 & 0 \\
\hline Main channel width (skewed), ft & 63.0 & 63.0 & 0.0 \\
\hline Cum. width of piers in MC, ft & 0.0 & 0.0 & 0.0 \\
\hline W, adjusted width, ft & 63 & 63 & 0 \\
\hline Y_bridge (avg. depth at br.), ft & 10.71 & 11.46 & ERR \\
\hline Dm, median $(1.25 * D 50)$, ft & 0.90875 & 0.90875 & 0 \\
\hline $\mathrm{y}^{2}$, depth in contraction, ft & 8.64 & 12.10 & ERR \\
\hline ys, scour depth (y2-ybridge), ft & -2.07 & 0.64 & $\mathrm{~N} / \mathrm{A}$ \\
\hline
\end{tabular}

Abutment Scour

Froehlich's Abutment Scour

$\mathrm{Ys} / \mathrm{Y} 1=2.27 * \mathrm{~K} 1 * \mathrm{~K} 2 *\left(\mathrm{a}^{\prime} / \mathrm{Y} 1\right) \wedge 0.43 * \mathrm{Fr} 1 \wedge 0.61+1$

(Richardson and others, 1995, p. 48, eq. 28)

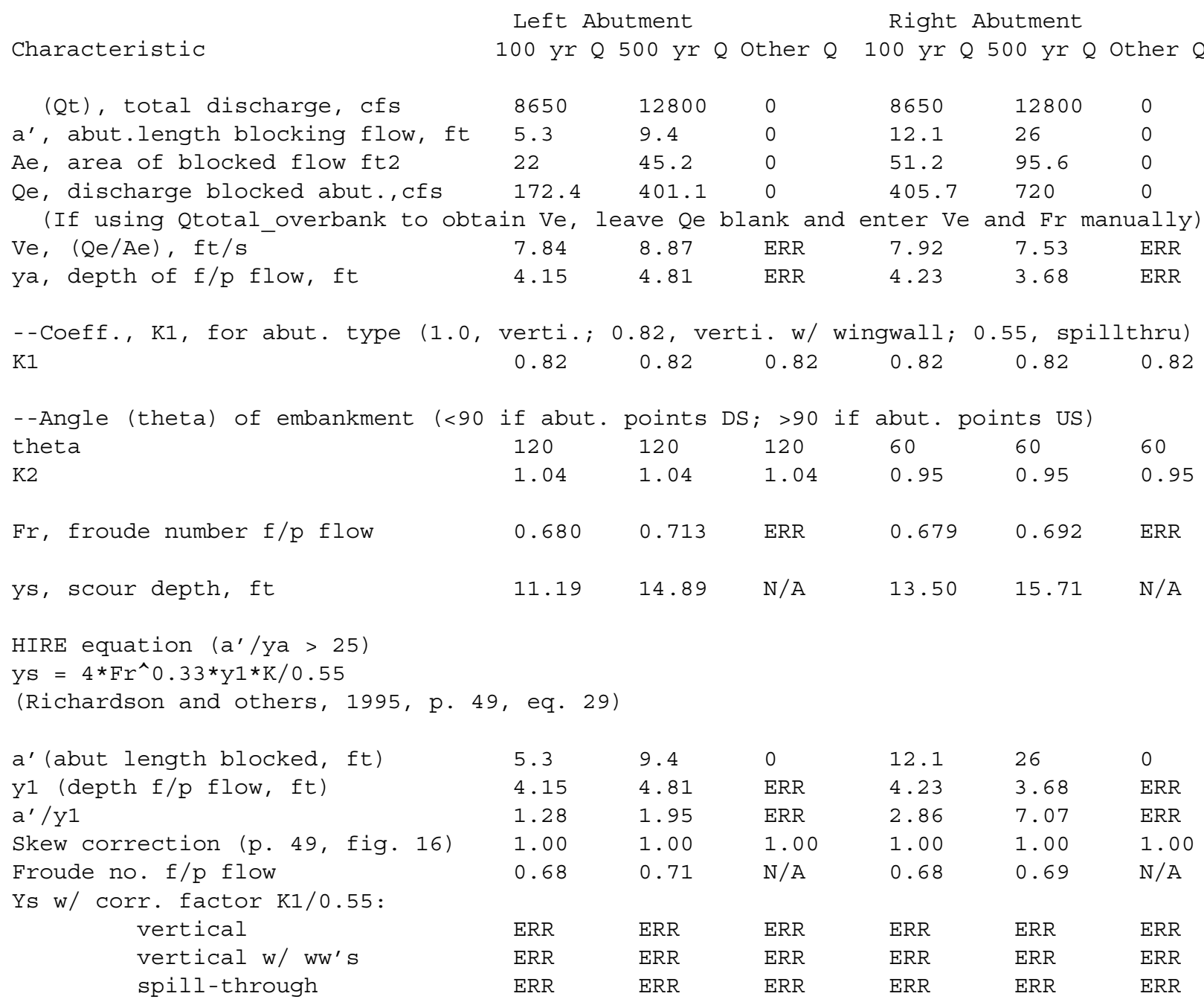




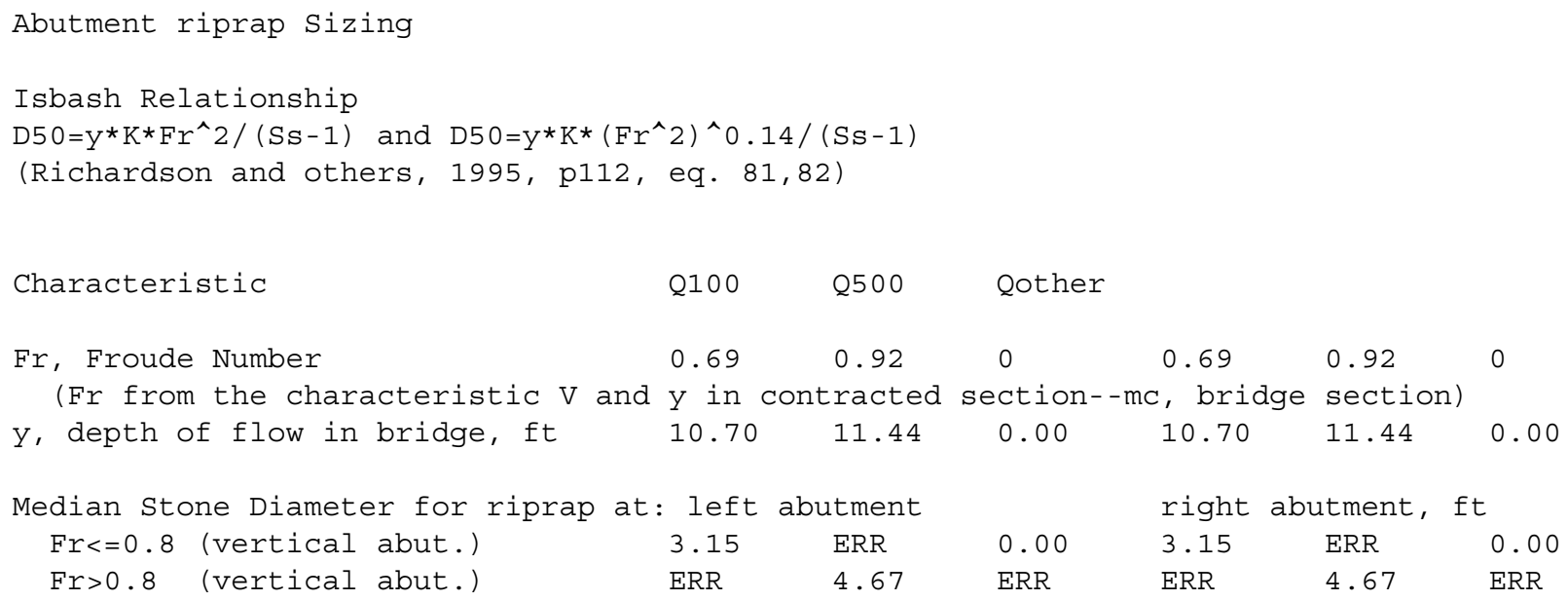

